\title{
HEINONLINE
}

Citation: 86 Minn. L. Rev. 1393 2001-2002

Content downloaded/printed from

HeinOnline (http://heinonline.org)

Fri Jul 27 16:14:51 2012

-- Your use of this HeinOnline PDF indicates your acceptance of HeinOnline's Terms and Conditions of the license agreement available at http://heinonline.org/HOL/License

-- The search text of this PDF is generated from uncorrected OCR text.

-- To obtain permission to use this article beyond the scope of your HeinOnline license, please use:

https://www.copyright.com/ccc/basicSearch.do?

\&operation $=$ go\&search Type $=0$

\&lastSearch $=$ simple\&all $=0$ \& \& titleOrStdNo $=0026-5535$

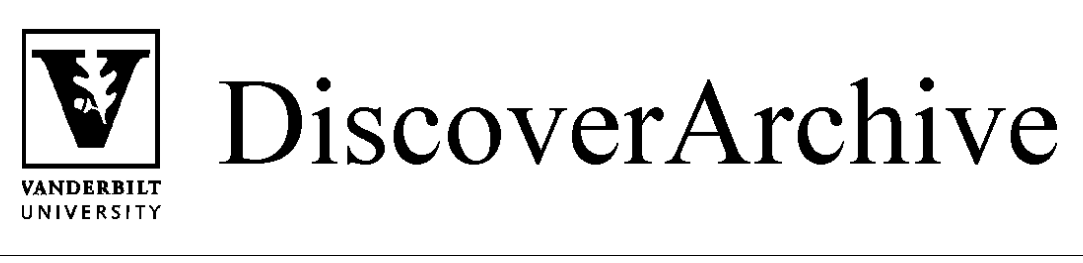

Retrieved from DiscoverArchive,

Vanderbilt University's Institutional Repository

This work was originally published in

86 Minn. L. Rev. 1393 2001-2002 


\section{Peeping Techno-Toms and the Fourth Amendment: Seeing Through Kyllo's Rules Governing Technological Surveillance}

\section{Christopher Slobogin $\uparrow$}

In Kyllo v. United States, ${ }^{1}$ the Supreme Court struck a blow for the sanctity of the home, in an age when technology threatens to destroy it. This Article wonders whether Kyllo is a pyrrhic victory.

Prior to Kyllo, the majority of lower courts had held that use of a thermal imaging device to detect heat sources within a house is not a Fourth Amendment search, either because the heat waves detected by such devices are "abandoned" and do not require physical intrusion to discern, or because they are too impersonal to warrant privacy protection. ${ }^{2}$ In Kyllo, the Supreme Court rejected these rationales, and concluded that the government may not mechanically measure the warmth of the home unless it demonstrates probable cause for doing so. ${ }^{3}$ The Court's decision could also be read to say that most other scientifically enhanced investigations of the domicile are

$\dagger$ Stephen C. O'Connell Professor of Law, University of Florida Fredric G. Levin College of Law. I want to thank Benjamin Diamond and Ryan Cobbs, my research assistants, for their help on this project, and the participants in the Minnesota Law Review's Symposium: Modern Studies in Privacy Law for their feedback. Copyright 2002 by Christopher Slobogin and the Minnesota Law Review.

1. 533 U.S. 27 (2001).

2. Professor LaFave states that, prior to Kyllo, the "overwhelming majority of appellate decisions" found that use of a thermal imager to detect items in a home was not a search. 1 WAYNE R. LAFAVE, SEARCH AND SEIZURE: A TREATISE ON THE FOURTH AMENDMENT \$ 2.2, at 74 (3d ed. Supp. 2002); see, e.g., United States v. Myers, 46 F.3d 668, 670 (7th Cir. 1995) (noting that a thermal imager "does not intrude in any way into the privacy and sanctity of a home" and detects only "waste products intentionally or inevitably exposed to the public") (in part quoting California v. Greenwood, 486 U.S. 35, 37 (1988)); United States v. Pinson, 24 F.3d 1056, 1059 (8th Cir. 1994) ("Detection of the heat waste was not an intrusion into the home; no intimate details of the home were observed, and there was no intrusion upon the privacy of the individuals within.").

3. See infra text accompanying notes 77-84. 
searches as well, ${ }^{4}$ and thus might indicate a desire to put significant restrictions on all technological surveillance of our most private sanctuary.

If so, the ruling is a good one. But the Court left at least one loophole in its decision, a loophole that could potentially be quite significant. Its precise holding stated that "[w]here, as here, the Government uses a device that is not in general public use, to explore details of the home that would previously have been unknowable without physical intrusion, the surveillance is a 'search."' As the dissenters in Kyllo rightly pointed out, varying Fourth Amendment regulation of technology on the prevalence of that technology is troublesome, because "the threat to privacy will grow, rather than recede, as the use of intrusive equipment becomes more readily available."

Much depends on how the Court defines "general public use." One might be comforted by the majority's insistence (indeed, it was "quite confident") that, despite its availability from over half a dozen national companies, ${ }^{8}$ the type of thermal imaging device at issue in Kyllo is not in general use. As this Article will document, ${ }^{9}$ however, today's marketplace offers a wide array of much cheaper enhancement devices, easily bought over the Internet and from nationwide chains and speciality shops. The march of progress guarantees that this trend will accelerate. Thus, the dissent's caution in Kyllo should be taken seriously.

The majority's sole response to this caution was the disqui-

4. See infra text accompanying notes $46-87$ for the various ways the opinion could be interpreted.

5. Kyllo, 533 U.S. at $\mathbf{4 0}$ (emphasis added).

6. Id. at 47 (Stevens, J., dissenting).

7. Id. at 39 n.6.

8. The record in Kyllo stated that close to 1000 units of the device in that case had been manufactured, that 4000 to 5000 units of its predecessor had been manufactured, and that another 5000 to 6000 units were on the market-all available for purchase or rental from "half a dozen national companies." Id. at 47 n.5; see also United States v. Ishmael, 48 F.3d 850, 856 n.6 (5th Cir. 1995) ('The [thermal imaging] technology is 'off the shelf', having been in general use for fifteen years.") (quoting United States v. Deaner, 1992 WL 209966, at *2 (M.D. Pa. July 27, 1992)). On the other hand, such imagers can be expensive, with a cheap version, the "Thermal Viewer," costing over $\$ 12,000$, see http://www.usnightvision.com, and higher resolution versions costing between $\$ 28,000$ and $\$ 50,000$, with high-end versions used from helicopters costing over $\$ 100,000$. Telephone Interview with Azar Louh, salesperson, FLIR Systems (Jan. 8, 2002) (FLIR stands for "Forward-Looking InfraRed").

9. See infra text accompanying notes 49-56. 
eting statement that the dissent's "quarrel ... is not with us but with this Court's precedent." Here, it cited California $v$. Ciraolo, ${ }^{11}$ which held, in the context of airplane flyovers, that the privacy protected by the Fourth Amendment is no greater than the privacy one can expect from the public at large-and a decidedly curious public at that (one composed, for instance, of members who look closely at plants growing in backyards from low-flying airplanes). ${ }^{12}$ If that is to be the Court's approach to police use of technology, then the Kyllo dissent may be right in its suggestion that the general use exception will eventually swallow the Court's newly minted prohibition of technologically enhanced investigation of homes. That prediction is, if anything, strengthened by Ciraolo's companion case, Dow Chemical Co. v. United States. ${ }^{13}$ There, the Court held that while "surveillance of private property by using highly sophisticated surveillance equipment not generally available to the public" might well require a warrant, use of a $\$ 22,000$, highmagnification mapmaking camera to surveil the exterior of secluded business premises does not. ${ }^{14}$

Ciraolo and Dow Chemical both involved observation of curtilage, not the inner domain of the house. Perhaps the Court will define "general public use" differently depending upon the target of the surveillance, and insist that police always obtain warrants to carry out technological searches of homes, as it did in Kyllo and in United States v. Karo, ${ }^{15}$ which held that use of a beeper to discover the contents of a house is a search. But the lower courts have not let walls get in the way of technological innovation. Several have held that observation of the home interior using flashlights, binoculars, and other, more sophisticated illumination and magnification devices is not always a search. ${ }^{16}$ Of course, binoculars and flashlights are much more ubiquitous than the newer search enhancers. But, as the Kyllo dissent implies, thermal imagers and beepers may be the binoculars and flashlights of tomorrow. More impor-

10. Kyllo, 533 U.S. at 39 n.6.

11. 476 U.S. 207 (1986).

12. Id. at 213-14 (holding that police identification of marijuana plants from a plane 1000 feet in the air was not a search, the Court stated, "[a]ny member of the public flying in this airspace who glanced down could have seen everything that these officers observed").

13. 476 U.S. 227 (1986).

14. Id. at 238.

15. 468 U.S. 705 (1984).

16. See infra notes $40-44$. 
tantly, even the more mundane types of technology can visit significant intrusion on home dwellers.

In this Article, I argue that the extent to which a particular technological device is used by the general public, and the related inquiries into whether it is "generally available" or "highly sophisticated," should be irrelevant to Fourth Amendment analysis. On a more fundamental level, I argue that the Court's willingness to equate Fourth Amendment privacy with freedom from naked eye observation, a willingness that is apparent in many of the Court's cases and that is codified in Kyllo, is inconsistent with the Fourth Amendment. ${ }^{17}$ Although the reasoning advanced here applies to all police investigative actions, the focus of this Article will be on the use of technology to investigate goings-on inside the home and similarly private locations. I treat use of technology to conduct surveillance of public areas in a sequel article. ${ }^{18}$

Part I of this Article briefly summarizes the law regarding both the general public use doctrine and what I will call the "naked eye doctrine" as they are described in Kyllo, other Supreme Court decisions, and the lower courts. Part II explains why these concepts are incoherent in practice and unsustainable in theory. Part III proposes two solutions to the problems posed by technological searches. The first is based on my previous work arguing for adoption of a proportionality principle, which dictates that "search" be defined broadly for Fourth Amendment purposes (so that any intentional surveillance of a house would require some suspicion), but also permits police to search on less than probable cause when their actions are not particularly intrusive. ${ }^{19}$ The second proposal is that Congress enact a statute prohibiting use of technological devices under circumstances analogous to those currently encapsulated in Title III with respect to eavesdropping instruments. ${ }^{20}$

The first proposal might strike some as a non-starter, given the Court's niggardly search jurisprudence on the one

17. Thus, although I agree with many of his criticisms of the Court's cases, I disagree with Professor Ku's suggestion, expressed in this symposium issue of Minnesota Law Review, that observation of the home with technology in general public use or with the naked eye is not governed by the Fourth Amendment. See Raymond Shih Ray Ku, The Founders'Privacy: The Fourth Amendment and New Technologies After Kyllo, 86 MINN. L. REV., 1325 (2002).

18. See Christopher Slobogin, Public Privacy: Technological Surveillance and the Right to Anonymity, Mrss. L.J. (forthcoming 2002).

19. See infra text accompanying notes 153-80.

20. See infra text accompanying notes 181-94. 
hand, ${ }_{2}^{21}$ and its apparent insistence, on the other hand, that those actions that are denominated searches be based on probable cause. ${ }^{22}$ But the Court has yet to define reasonable expectations of privacy in connection with technologically enhanced house searches, so it is not too late to adopt an expansive view of "search" in this particular context. As for the probable cause dogma, the lower courts, which have to deal with the run-ofthe-mill case on a daily basis, have often ignored it, something the Supreme Court has come close to doing as well. ${ }^{23}$

If the proportionality approach is viewed as too radical, the second proposal is offered as a worthy substitute. Generally, that proposal would criminalize non-consensual technological surveillance of home interiors and similar locations by civilians. If that law goes into effect, visual surveillance devices would never lawfully be in "general use" for the purpose of spying on homes and the like, and that reality would in turn render the general public use exception as applied to private areas irrelevant, even as technology becomes more prevalent.

\section{THE GENERAL PUBLIC USE AND NAKED EYE EXCEPTIONS}

The general public use doctrine is of ephemeral origins. Perhaps as a result, its scope is very imprecise. Also unclear is how it interacts with other factors relevant to Fourth Amendment analysis, including the naked eye exception. These three matters are explored below.

\section{A. GENESIS}

Until the 1960s, the Fourth Amendment protected against government trespass in any of the four areas named in the Fourth Amendment-houses, persons, papers, and effects. ${ }^{24}$

21. See 1 LAFAVE, supra note $2, \$ 2.1$ (d), at 394 (3d ed. 1996) ("Too often the Court has failed to appreciate that privacy is not a discrete commodity, possessed absolutely or not at all, and that there is a dramatic difference, in privacy terms, between revealing bits and pieces of information sporadically to a small and often select group for a limited purpose and a focused police examination of the totality of that information regarding a particular individual.") (citation omitted).

22. Arizona v. Hicks, 480 U.S. 321, 328 (1987) ("A dwelling-place search, no less than a dwelling-place seizure, requires probable cause ....").

23. See infra text accompanying notes 172-79.

24. Silverman v. United States, 365 U.S. 505, 510 (1961) (noting that the crux of the Court's search cases up to that time was whether the police investigation was "accomplished by means of an unauthorized physical encroach- 
Under that approach, the prevalence of technology the police used was irrelevant. The sole inquiry was whether operation of the technology required intrusion into a protected area. If so, a search occurred; if not, then the Fourth Amendment was not implicated. ${ }^{25}$

Katz $v$. United States ${ }^{26}$ supposedly changed all that. In Katz, the Court held that police bugging of a phone booth is a search. Even though a phone booth is not a house, person, paper, or effect, and even though the bugging device did not physically intrude into it, the Court concluded that Katz's Fourth Amendment interests were infringed by the police action. ${ }^{27}$ Justice Harlan's suggestion, in his concurring opinion, ${ }^{28}$ that the Fourth Amendment protects expectations of privacy "that society is prepared to recognize as 'reasonable" has become the most prominent explanation for this result, as well as the guiding principle of search and seizure law more generally. ${ }^{29}$ But Justice Stewart's majority opinion in Katz contains many pithy phrases that continue to be cited as well. The most prominent of these, for purposes of exploring the general public use doctrine and its relationship to surveillance of homes, is his statement that "[w]hat a person knowingly exposes to the public, even in his own home or office, is not a subject of Fourth Amendment protection."

In Ciraolo, the Supreme Court relied on that formulation in concluding that naked eye observation, from an airplane flying at 1000 feet, of a backyard surrounded by a ten-foot high fence is not a search. ${ }^{31}$ In context, the Court's use of this aspect of Katz is instructive:

The Fourth Amendment protection of the home has never been extended to require law enforcement officers to shield their eyes when passing by a home on public thoroughfares. Nor does the mere fact

ment within a constitutionally protected area").

25. Compare id. at 509 (holding a search occurred because the "spike mike" used by police touched a part of the defendant's house), with Olmstead v. United States, 277 U.S. 438, 464 (1928) (holding that wiretapping was not a search because there was "no entry of the houses and offices of the defendants").

26. 389 U.S. 347 (1967).

27. See id. at 351-52.

28. Id. at 361 (Harlan, J., concurring).

29. See 1 LAFAVE, supra note $2, \S 2.1$ (b), at 384 ("Lower courts attempting to interpret and apply Katz quickly came to rely upon the Harlan elaboration, as ultimately did a majority of the Supreme Court . . . .") (citation omitted).

30. Katz, 389 U.S. at 351.

31. California v. Ciraolo, 476 U.S. 207, 214 (1986). 
that an individual has taken measures to restrict some views of his activities preclude an officer's observations from a public vantage point where he has a right to be and which renders the activities clearly visible.... "What a person knowingly exposes to the public, even in his own home or office, is not a subject of Fourth Amendment protection."

The observations ... in this case took place within public navigable airspace, in a physically nonintrusive manner .... Any member of the public flying in this airspace who glanced down could have seen everything that these officers observed. On this record, we readily conclude that respondent's expectation that his garden was protected from such observation is unreasonable and is not an expectation that society is prepared to honor. ${ }^{32}$

The Court used the same reasoning in Florida v. Riley, ${ }^{33}$ where it held that observing a backyard from a helicopter, this time only 400 feet about the ground (but still in navigable airspace), is not a search. ${ }^{34}$ In both cases, the Court assumed that members of the public might engage in the type of behavior the police did, and reasoned from that assumption that the behavior did not offend reasonable expectations of privacy.

In neither Ciraolo or Riley did the Court focus on the fact that the police were using technology (aircraft) to carry out their observations. In Ciraolo, however, the Court did state that "[i]n an age where private and commercial flight in the public airways is routine, it is unreasonable for respondent to expect that his marijuana plants were constitutionally protected from being observed with the naked eye from an altitude of 1,000 feet." ${ }^{35}$ It was this sentence that the Court would later cite in Kyllo in support of its general public use exception to technological surveillance of the home. ${ }^{36}$

Although a companion case to Ciraolo, Dow Chemical's contribution to the general public use exception was formulated somewhat differently. In finding that the Environmental Protection Agency's use of a $\$ 22,000$ mapmaking camera to photograph Dow Chemical's plant was not a search, ${ }^{37}$ the Court fo-

32. Id. at 213-14 (citations omitted).

33. 488 U.S. 445 (1989).

34. Id. at 451 ("Any member of the public could legally have been flying over Riley's property in a helicopter at the altitude of 400 feet and could have observed Riley's greenhouse.").

35. 476 U.S. at 215.

36. Kyllo v. United States, 533 U.S. 27, 39 n.6 (2001).

37. The lower court found that the camera used to view Dow's plant "cost in excess of $\$ 22,000.00$." Dow Chem. Co. v. United States, 476 U.S. 227, 242 n.4 (1986) (Powell, J., dissenting) (quoting United States v. Dow Chem. Co., 536 F. Supp. 1355, 1357 n.2 (E.D. Mich. 1982)). 
cused on the camera's availability and capabilities rather than its prevalence. Again, the relevant language is worth looking at in context.

It may well be, as the Government concedes, that surveillance of private property by using highly sophisticated surveillance equipment not generally available to the public, such as satellite technology, might be constitutionally proscribed absent a warrant. But the photographs here are not so revealing of intimate details as to raise constitutional concerns. Although they undoubtedly give EPA more detailed information than naked-eye views, they remain limited to an outline of the facility's buildings and equipment. The mere fact that human vision is enhanced somewhat, at least to the degree here, does not give rise to constitutional problems. ${ }^{38}$

This language, like the opinion in Ciraolo, makes clear that the extent to which the public has access to given technology is only one of many considerations in the Fourth Amendment calculus. More will be said about this multi-factor approach below. ${ }^{39}$ For now, it is enough to observe that the foregoing cases represent the sum total of the Supreme Court's pronouncements on the general public use concept. On this score, the lineage from Katz to Kyllo is thin indeed.

The lower courts, in contrast, provide many pre-Kyllo examples of judicial reliance on the general public use rationale. For instance, in State $v$. Vogel, the court held that police use of a camera with a zoom lens to photograph the interior of a residence was not a search, in part because there was "no showing that the cameras and lenses used [were] sophisticated visual aids" or "special equipment not generally in use." 40 In State $v$. Rose, the court concluded that use of a flashlight to aid peering into a mobile home is not a search in part because a flashlight is "an exceedingly common device." ${ }^{41}$ Several cases have used the same kind of language in concluding that no search occurs when police use zoom or other magnification lenses to observe curtilage. $^{42}$

38. Id. at 238.

39. See infra text accompanying notes 63-87.

40. 428 N.W.2d 272,275 (S.D. 1988).

41. 909 P.2d 280, 286 (Wash. 1996).

42. See, e.g., United States v. Van Damme, 48 F.3d 461, 463 (9th Cir. 1995) ("A $35 \mathrm{~mm}$ camera with a $600 \mathrm{~mm}$ lens is a kind of vision enhancer commonly available to the public and used typically for telephoto landscape photography.”); United States v. Allen, 675 F.2d 1373, 1380 (9th Cir. 1980) (use of a special lens is not a search because "[s]uch equipment is widely available commercially"); State v. Lange, 463 N.W.2d 390, 395 (Wis. Ct. App. 1990) ("We specifically limit our holding here to approval of the use of standard binoculars and cameras equipped with generally available standard and 
A number of other decisions have permitted enhanced observation of home interiors or curtilage-using devices ranging from binoculars to startrons (which are essentially night scopes with magnification capacity)—without specifically mentioning the general public use concept. But they either have clearly assumed that such visual enhancement does not change the Fourth Amendment analysis, ${ }^{43}$ or have noted that the use of more sophisticated devices might have changed the result. ${ }^{44}$ Thus, the routine use and general availability notions briefly alluded to in Ciraolo and Dow Chemical have heavily influ-

zoom lenses.").

43. See, e.g., People v. Ferguson, 365 N.E.2d 77, 79 (Ill. App. Ct. 1977) (use of binoculars to look through the windows of a second floor apartment from 60 feet away); People v. Hicks, 364 N.E.2d 440, 442 (IIl. App. Ct. 1977) (use of night binoculars to look in a hotel room window at 1:00 a.m.); State v. Littleton, 407 So. 2d 1208, 1210 (La. 1981) (use of binoculars to look into a hangar with a thirty- to forty-foot wide opening); People v. Ward, 308 N.W.2d 664, 667 (Mich. Ct. App. 1981) (observation through a telephoto lens to look in a home); State v. Thompson, 241 N.W.2d 511, 512 (Neb. 1976) (use of binoculars to look into house windows); State v. Louis, 672 P.2d 708, 709 (Or. 1983) (use of a telephoto lens to observe a person repeatedly positioning self at window); Commonwealth v. Williams, 396 A.2d 1286, 1289-90 (Pa. Super. Ct. 1979) (use of binoculars and startron to look in a home); Commonwealth v. Hernley, 263 A.2d 904, 905 (Pa. Super. Ct. 1971) (use of binoculars to look into printing shop); State v. Manly, 530 P.2d 306, 307 (Wash. 1975) (use of binoculars to look into a home). The Supreme Court has made statements consistent with these holdings, albeit in cases involving targets outside the home. See Texas v. Brown, 460 U.S. 730, 740 (1983) (stating that "the use of artificial means to illuminate a darkened area simply does not constitute a search" in the context of a car search); On Lee v. United States, 343 U.S. 747, 754 (1952) (stating that "[t]he use of bifocals, field glasses or the telescope to magnify the object of a witness' vision is not a forbidden search or seizure, even if they focus without his knowledge or consent upon what one supposes to be private indiscretions" in the context of shining a searchlight on a boat). But see United States v. Taborda, 635 F.2d 131, 139 (2d Cir. 1980) (use of binoculars to look in a home deemed a search); United States v. Kim, 415 F. Supp. 1252, 1257-58 (D. Haw. 1976) (same); People v. Arno, 153 Cal. Rptr. 624, 626 (Cal. Ct. App. 1979) (same).

44. See, e.g., People v. Oynes, 920 P.2d 880, 883 (Colo. Ct. App. 1996) ("Absent evidence in the record indicating that the deputy's binoculars were extraordinarily powerful, we conclude that the observation [of a housel was not a "search" for constitutional purposes."); Bernstiel v. State, 416 So. $2 \mathrm{~d} 827$, 828 (Fla. Dist. Ct. App. 1982) (stating that the use of binoculars to look in a greenhouse is not a search because "the emphasis appears to be on the danger imposed by more sophisticated devices such as telescopes"); State v. Stachler, 570 P.2d 1323, 1328 (Haw. 1977) (stating that the use of binoculars to look in a backyard is not a search but "[i]f the lower court had found ... that highly sophisticated viewing devices had been employed, we might well decide differently"). 
enced the lower courts. ${ }^{45}$

\section{B. DEFINITIONS}

Despite the number of cases mentioning the issue, the general public use concept remains amorphous. As noted above, a number of courts seem to believe that flashlights and binoculars, and perhaps night scopes as well, are in general public use. The Supreme Court has indicated that airplanes (in navigable airspace) and mapmaking cameras are as well, but that thermal imagers and (probably) beepers are not. But no court has put forth a more general definition of the concept. Given the Supreme Court's use of the term in Kyllo, that effort will probably soon be forthcoming. In the meantime, the thumbnail sketch of the caselaw provided above suggests three basic definitions, each of which is itself divisible into two or more versions.

The first basic definition focuses on whether the technology in question is "generally available to the public"-the language found in Dow Chemical. "Generally" means "usually" or "as a rule, ${ }^{\$ 46}$ while "general" means "applicable to the whole.,47 "Available" means "accessible" or "obtainable," or "ready for immediate use." ${ }^{48}$ On these understandings, a generally available item is one that all or virtually all members of the public are able to obtain. Taken literally, this definition would exclude much surveillance technology, except perhaps the cheapest flashlights. It would certainly not encompass mapmaking cameras or low-flying airplanes, suggesting that this is not the definition the Court would endorse.

Moving to a broader definition (although still not as broad as Dow Chemical's), general availability could be construed to mean that the item is available to a substantial portion of the public. Under this definition, indicia of general availability might be the number of items manufactured, the cost of the

45. In his survey of the caselaw, Professor LaFave lists "the level of sophistication of the equipment utilized by the police" as one of "two primary considerations" relevant to "assessing in a particular case whether [an] expectation [of privacy in the home] was in fact justified." 1 LAFAVE, supra note 2, at 421 . The other consideration is "the extent to which the incriminating objects or actions were out of the line of normal sight from contiguous areas where passersby or others might be." Id.

46. WEBSTER'S NEW COLLEGIATE DICTIONARY 478 (1973).

47. Id.

48. Id. at 77 . 
item, and the number of outlets carrying it. More colloquially, this definition could be dubbed the "Wal-Mart test." If the item is available at Wal-Mart, it is likely to be affordable to and accessible by a large segment of the public.

Clearly flashlights are generally available in this sense. They are usually inexpensive (a high-beam version comes as low as $\$ 8.00$, batteries included), and can be purchased at nationwide stores such as Wal-Mart, K-Mart, and Target, as well as numerous local stores. ${ }^{49}$ Binoculars are not as prevalent, but are still relatively cheap, ranging from $\$ 9.00$ for a pair with a magnification capacity of $4(4 \times)$ to $\$ 55.00$ for binoculars with $12 \mathrm{x}$ power. $^{50}$ Cameras equipped with zoom lenses are also fairly easy to purchase, with Wal-Mart prices ranging from $\$ 60.00$ to $\$ 100.00$ for cameras with $2 \mathrm{x}$ to $4 \mathrm{x}$ magnification power. ${ }^{51}$ This much is common knowledge.

What might be somewhat surprising is that Wal-Mart also offers inexpensive versions of highly powerful telescopes and night vision equipment. The Tasco Luminova Telescope costs only $\$ 59.87$ and has a magnification power of $578 .^{52}$ The Night Owl Light Night Vision Monocular costs only $\$ 129.87$, has infrared capacity, and has a magnification power of $3.1 x^{53}$

Moving from Wal-Mart to speciality stores, one encounters a veritable cornucopia of inexpensive surveillance goodies. These include cheap five-power binoculars, with night vision up to 50 feet (for only $\$ 11.95$ ! (5) $^{5}$ to state-of-the-art night vision scopes starting at under $\$ 200.00 .^{55}$ These devices may not be in

49. This assertion is based on a recent shopping trip taken by the Author.

Prices of these or similar items can also be found at http://www.walmart.com.

50. See id.

51. See id.

52. See id.

53. See id.

54. See www.pgtechnologies.com (last visited June 15, 2002); see also www.wildplanet.com ("Spynight Scope" features "green tinted lenses [that] aid night-time surveillance"; secret agents need only "press a button and the stealth green spotlight pops up to shine as far as 25 feet away!") (last visited June 15, 2002).

55. See, e.g., http://www.binoculars.com/model.asp?PID=5713 (featuring the Bushnell Compact Monocular, with 1.7x magnification and an "[i]nfrared illuminator for viewing in complete darkness" for $\$ 149.00$ ) (last visited Feb. 2, 2002). For under $\$ 250.00$, one can also purchase receivers that will surreptitiously pick up the signals sent by "nanny-cameras" and other securityoriented video surveillance, allowing "eyesdroppers" to see the insides of homes and businesses unbeknownst to those who set up the cameras. John Schwartz, Nanny-Cam May Leave a Home Exposed, N.Y. TIMES, Apr. 14, 2002, at 1. 
every home, but they are certainly much more "available" to the general public than seats on airplanes, and much less sophisticated than the $\$ 22,000$ mapmaking camera in Dow Chemical.

A second, less expansive basic definition of the general public use concept adheres more closely to the words in that phrase: How often does the public use a particular type of technology? Generally available items may not be commonly resorted to. For instance, although most of the aforementioned devices are obtainable by a sizeable portion of the public, their use is quite varied; people rely on flashlights all the time, binoculars and zoom lenses somewhat less frequently, and telescopes and night vision equipment less frequently still.

At the same time, all of these items are everyday paraphernalia to certain segments of the population, and are relied upon at least as frequently as low-flying airplanes in carrying out certain types of endeavors. Birdwatchers, sports fans, and hunters make avid use of binoculars. Tourists and loving families focus their zoom lenses on a daily basis. Telescopes are a favorite of stargazers, and night vision devices are popular with hunters. The number of these groupings and their size will only expand as time marches on. ${ }^{56}$ Also worth noting is the Court's apparent endorsement of this "subgroup" approach to the general use doctrine in Dow Chemical, where it emphasized that the device relied on in that case was "a conventional, albeit

56. With respect to night vision equipment, consider this excerpt from the introduction to a report on use of visual surveillance devices:

The current "Gen III" or "Third Generation night vision devices have

become much less expensive, more reliable, and more widespread in nonmilitary use.... [V]isual surveillance technologies once reserved solely for military or police use, such as night vision devices, have been dramatically reduced in price, and are entering the civilian market in ever increasing numbers.... [A]s microminiaturization of these technologies proceeds, the presence of surveillance devices in our daily lives is becoming ever more pervasive, and increasingly without our knowledge or awareness. ... [B]y 2004, it can be expected that growth in the visual surveillance device market will result in mergers and acquisitions in the security industry that depends on these devices.... [T]he visual surveillance device industry is a growth industry, which will see substantial growth in industrial, commercial and residential applications well into the next century, with a consequent eroding of personal privacy.

George Samerjan, Visual Surveillance Devices: New Opportunities (May 2000), available at http://www.buscom.com/safety/G241.html. The full report, which predicts market trends with respect to night vision and closed circuit TV, costs $\$ 3450.00$. See id. 
precise, commercial camera commonly used in mapmaking. ${ }^{, 57}$

That observation leads to a third basic definition that is even narrower-general public use for a particular purpose. Most of these devices, even if generally available and used by large segments of the public, are not usually used the way police use them. In particular, they are probably not normally employed to look into homes or curtilage.

As the Court demonstrated in Riley, there are several versions of this approach as well. A plurality of justices in that case (including Justice Scalia, author of $K y l l o$ ) adopted what might be called a "positivist" approach, finding the fact that planes could legally fly within 400 feet of the ground dispositive of the issue of whether observation of curtilage from that height was a search. ${ }^{58}$ This stance, as the Riley dissent pointed out, in essence asserts that "the expectation of privacy is defeated if a single member of the public could conceivably position herself to see into the area in question without doing anything illegal. ${ }^{359}$

The other five Justices took an "empirical" approach to that issue. Justice O'Connor, in a concurring opinion, concluded that if overflights at 400 feet are "rare," then they should be considered searches even though technically in navigable airspace (although she ended up deciding they were not rare in this particular area, and thus joined the plurality in finding that no search occurred in Riley). ${ }^{60}$ The four dissenters in Riley fine-tuned the empirical approach further, asking whether overflights at 400 feet for the specific purpose of observing the contents of residential backyards are rare, ${ }^{61}$ and deciding that

57. Dow Chem. Co. v. United States, 476 U.S. 227, 238 (1986).

58. The dissent asserted that, according to the majority, "it is the FAA regulations rather than any empirical inquiry that is determinative," a characterization that seems accurate. Florida v. Riley, 488 U.S. 445, 461 n.5 (1989) (Brennan, J., dissenting).

59. Id. at 457.

60. Id. at 455 (O'Connor, J., concurring) ("Because there is reason to believe that there is considerable public use of airspace at altitudes of 400 feet and above, and because Riley introduced no evidence to the contrary before the Florida courts, I conclude that Riley's expectation that his curtilage was protected from naked-eye aerial observation from that altitude was not a reasonable one.").

61. Justice Brennan's dissent, joined by Justice Marshall and Justice Stevens, stated that "[t] he question before us must be not whether the police were where they had a right to be, but whether public observation of Riley's curtilage was so commonplace that Riley's expectation of privacy in his backyard could not be considered reasonable." Id. at 460 (Brennan, J., dissenting). Jus- 
they were exceedingly so. ${ }^{62}$

\section{INTERACTION WITH OTHER FACTORS}

In addition to the definitional ambiguity, another potential source of confusion about the general public use doctrine is that it is only one of many factors possibly relevant to the search issue. For instance, after Dow Chemical, aiming a mapmaking camera from an airplane is not a search if the target is business curtilage, but, as the Court suggested in Dow Chemical, it may become a search if the interior of the home is the focus. ${ }^{63}$ Shining a flashlight in a car window ${ }^{64}$ or the open door of barn situated in open fields $s^{65}$ may be treated differently than use of that device to look into a bedroom window.

In other work, I have identified seven factors the courts often look at in determining whether police use of technology is a search. In addition to the availability of the technology to the general public, courts consider six other factors: (1) the nature of the place to be observed; (2) the steps taken to enhance privacy; (3) the degree to which the surveillance requires a physical intrusion onto private property; (4) the nature of the object or activity observed; (5) the extent to which the technology enhances the natural senses; and (6) the extent to which the surveillance is unnecessarily pervasive, invasive, or disruptive (i.e., steps taken by the police to minimize the intrusion). ${ }^{66}$

tice Blackmun, who wrote a separate dissent, similarly stated that "answering [the search] question depends upon whether Riley has a 'reasonable expectation of privacy' that no such surveillance would occur, and does not depend upon the fact that the helicopter was flying at a lawful altitude under FAA regulations." Id. at 467 (Blackmun, J., dissenting).

62. Id. at 465 (Brennan, J., dissenting) ("I think we could take judicial notice that, while there may be an occasional privately owned helicopter that flies over populated areas at an altitude of 400 feet, such flights are a rarity and are almost entirely limited to approaching or leaving airports or to reporting traffic congestion near major roadways."). Justice Blackmun agreed: "I believe that private helicopters rarely fly over curtilages at an altitude of 400 feet," but concluded that the case should be remanded to permit the prosecution to show the rarity of such flights. Id. at 468 (Blackmun, J., dissenting)

63. Dow Chem. Co. v. United States, 476 U.S. 227, 237 n.4 (1986) ("We find it important that [the area surveilled] is not an area immediately adjacent to a private home, where privacy expectations are most heightened.").

64. See Texas v. Brown, 460 U.S. 730, 739-40 (1983) (holding that looking into the interior of a car with the aid of a flashlight is not a search).

65. See United States v. Dunn, 480 U.S. 294, 305 (1987) (holding that looking into the interior of a barn outside the curtilage with the aid of a flashlight is not a search).

66. Christopher Slobogin, Technologically-Assisted Physical Surveillance: 
Ciraolo, Riley, and Dow Chemical can be used to illustrate each of these six factors. With respect to the nature of the area surveilled, all three cases emphasized that the home and immediate surrounding curtilage are accorded the most significant privacy protection. ${ }^{67}$ On the issue of privacy enhancement, Ciraolo noted that the ten-foot high fence in that case, although clearly meant to shield the backyard from street-level viewing, would not have barred observers on trucks or busses from seeing the marijuana, ${ }^{68}$ and in Dow Chemical, the Court scoffed at Dow's assertion that keeping track of the identification numbers of overflights was an adequate precaution against privacy invasion. $^{69}$ All three cases also emphasized that the overflight did not require physical intrusion onto the property. ${ }^{70}$

Concerning the nature of the activity observed, the majority opinions in Dow Chemical and Riley asserted that the helicopter observers did not see any "intimate" activities in the backyard. ${ }^{71}$ With respect to the potency of the enhancement used, Dow Chemical distinguished the camera observation in that case from technological observation that can see through

The American Bar Association's Tentative Draft Standards, 10 HARV. J.L. \& TECH. 383, 389-98 (1997).

67. California v. Ciraolo, 476 U.S. 207, 213 (1986) (referring to the home and curtilage as the area "where privacy expectations are most heightened"); Riley, 488 U.S. at 452 (noting that "no intimate details connected with the use of the home or curtilage were observed"); Dow Chem., 476 U.S. at 237 n.4 ("We find it important that this is not an area immediately adjacent to a private home, where privacy expectations are most heightened."). It is interesting to note, however, that none of these cases made a distinction between the home and the curtilage in terms of privacy protection.

68. Ciraolo, 476 U.S. at 211 ("Yet a 10-foot fence might not shield these plants from the eyes of a citizen or a policeman perched on the top of a truck or a two-level bus.").

69. Dow Chem., 476 U.S. at 237 n.4 ("Simply keeping track of the identification numbers of any planes flying overhead, with a later follow-up to see if photographs were taken, does not constitute a 'procedur[e] designed to protect the facility from aerial photography."').

70. Ciraolo, 476 U.S. at 213 (noting that the observations by the police "took place... in a physically nonintrusive manner"); Riley, 488 U.S. at 452 ("Neither is there any intimation here that the helicopter interfered with respondent's normal use of the greenhouse or of other parts of the curtilage."); Dow Chem., 476 U.S. at 237 ("Any actual physical entry by EPA into any enclosed area would raise significantly different questions ....").

71. Riley, 488 U.S. at 452 (noting that "no intimate details connected with the use of the home or curtilage were observed"); Dow Chemical, 476 U.S. at 238 (noting that "the photographs here are not so revealing of intimate details as to raise constitutional concerns"). 
walls. $^{72}$ And on the issue of minimization, Riley noted that the helicopter caused "no undue noise" nor any "wind, dust, or threat of injury.",73

Lower courts dealing with technologically enhanced searches of homes mention similar factors. The most frequently noted are steps taken to enhance privacy (were curtains drawn, fences erected?) and the vantage point of the observer (was he in public space, or private space into which the public is explicitly or implicitly invited?). ${ }^{74}$ But no particular factor is ascribed priority in the analysis.

Given the numerous variables that courts consider in assessing reasonable expectations of privacy, how important is the general public use factor when assessing the Fourth Amendment implications of enhanced observation of the home, the subject of Kyllo (and this Article)? Kyllo suggests that, whatever may have been the case in the past, it is very important to the current Court in that particular setting. Further, Kyllo suggests that most, if not all, of the other factors (that is, factors (2) through (6) above) are of secondary importance or are entirely irrelevant in deciding whether such observation is a Fourth Amendment search. While affirming that the "interior of the home" is accorded full Fourth Amendment protection, ${ }^{75}$ and twice stating the general public use exception to that rule, ${ }^{76}$ the decision implicitly or explicitly downplays at least four of the other five factors identified above.

To verify this point, consider Kyllo's treatment of each factor, in the same order as above, beginning with steps taken to enhance privacy. On this issue, the Kyllo majority was the most opaque, for it did not directly address the dissent's point that the defendant could have avoided the discovery of the heat waves by "mak[ing] sure that the surrounding area [was] well insulated." Perhaps the majority did not think the matter important enough to address, or perhaps (as explained below) this factor still does remain crucial. In contrast, the majority

72. 476 U.S. at 239 ("An electronic device to penetrate walls or windows so as to hear and record confidential discussions of chemical formulae or other trade secrets would raise very different and far more serious questions ...."). The Court also distinguished the photography in Dow Chemical from satellite photography. Id. at 238.

73. 488 U.S. at 452.

74. See cases cited supra note 43 .

75. Kyllo v. United States, 533 U.S. 27, 34, 39 (2001).

76. Id.

77. Id. at 45 (Stevens, J., dissenting). 
forthrightly dismissed the dissent's argument that the imager "did not penetrate the walls of petitioner's home," stating, "[w]e rejected such a mechanical interpretation of the Fourth Amendment in Katz, where the eavesdropping device picked up only sound waves that reached the exterior of the phone booth." ${ }^{\prime 9}$ To the assertion that the thermal imager detected no intimate details, ${ }^{80}$ the majority once again minced no words: "In the home, our cases show, all details are intimate details, because the entire area is held safe from prying government eyes." ${ }^{\text {i1 }}$ And the dissent's attempt to show-through its observations about the various other ways the heat inside Kyllo's home could have been detected ${ }^{82}$ - that the imager merely replicated what careful unenhanced surveillance would have discerned was "quite irrelevant" to the majority. ${ }^{83}$ The majority continued:

The fact that equivalent information could sometimes be obtained by other means does not make lawful the use of means that violate the Fourth Amendment. The police might, for example, learn how many people are in a particular house by setting up year-round surveillance; but that does not make breaking and entering to find out the same information lawful. In any event, on the night of January 16, 1992 [the date of the surveillance], no outside observer could have discerned the relative heat of Kyllo's home without thermal imaging.

Although the final variable-concerning steps taken to minimize the surveillance-was left unaddressed by the Kyllo majority, presumably that factor too is "irrelevant" when the

78. Id. at 44-46 (Stevens, J., dissenting) (noting that the imager did not "penetrate" the walls and that "[w] hat was involved in this case was nothing more than drawing inferences from off-the-wall surveillance, rather than any 'through-the-wall' surveillance").

79. Id. at 35 .

80. Id. at 37 (noting that "[t]he Government also contends that the thermal imaging was constitutional because it did not 'detect private activities occurring in private areas"); see also id. at 44 (Stevens, J., dissenting) (arguing that the imager "did not obtain 'any information regarding the interior of the home").

81. Id. at 37.

82. Id. at 43 (Stevens, J., dissenting).

Indeed, the ordinary use of the senses might enable a neighbor or passerby to notice the heat emanating from a building, particularly if it is vented, as was the case here. Additionally, any member of the public might notice that one part of a house is warmer than another part or a nearby building if, for example, rainwater evaporates or snow melts at different rates across its surfaces.

Id.

83. Id. at $35 \mathrm{n} .2$.

84. Id. 
surveillance is of the home. If all activities therein are intimate, then no amount of minimization suffices.

Before concluding, however, that general public use is the only factor relevant to deciding whether sense-enhanced surveillance of the home is a search, look one more time at the holding in Kyllo: "Where, as here, the Government uses a device that is not in general public use, to explore details of the home that would previously have been unknowable without physical intrusion, the surveillance is a 'search'...." $8{ }^{85}$ In an earlier phrasing of its holding, the Court stated, "We think that obtaining by sense-enhancing technology any information regarding the interior of the home that could not otherwise have been obtained without physical intrusion into a constitutionally protected area' constitutes a search-at least where (as here) the technology in question is not in general public use. ${ }^{386}$ The italicized portions of these statements, taken together, announce that if the activity observed could be seen with the naked eye without physical intrusion into the constitutionally protected areas of home or curtilage, then police may exploit any technology-generally used or not-without implicating the Fourth Amendment (whereas, as we have been discussing, if the activity cannot be viewed with the naked eye in the absence of physical intrusion, the police may only use common technology to conduct warrantless enhanced surveillance).

This second exception to the general prohibition on enhanced surveillance of the home interior-what I am calling the "naked eye" exception-suggests that at least one other factor besides general public use is still important in assessing enhanced home observation. Steps taken to enhance privacy, such as drawing curtains over windows or fencing off one's yard, may continue to be relevant after $K y l l o$ because they curtail naked eye observation of the interior of the home from outside the house. In the absence of such steps, naked eye viewing without physical intrusion is more likely, in which case Kyllo allows police use of any technology available to view the same details.

After Kyllo, the determination of whether technologically enhanced surveillance of the interior of the home is a search depends on two factors: whether the technology is in general

85. Id. at 40 (emphasis added).

86. Id. at 34 (quoting Silverman v. United States, 365 U.S. 505, 512 (1961)) (emphasis added). 
public use and, if it is not, whether the technologically enhanced surveillance detects only details that would have been viewable without technology, from an area unprotected by the Constitution. If either the general public use or the naked eye exception applies, then no search has occurred. ${ }^{87}$ It is now time to examine whether any of this makes sense.

\section{KYLLO'S PROBLEMS}

To the extent it endorses the general public use concept or the related idea that details viewable by the naked eye without physical intrusion also may be viewed with technology, the ruling in Kyllo is seriously flawed. This Part demonstrates that conclusion from three perspectives. The first is the most pragmatic: Both the general public use and the naked eye doctrines are virtually impossible to apply in a meaningful manner. The second perspective is more theoretical: Despite the courts' insinuation to the contrary, these two concepts cannot, as a logical matter, flow from Katz's 'knowing exposure" language. The third perspective is blatantly normative: Members of our society should be constitutionally entitled to expect that government will refrain from any spying on the home--technological or otherwise-unless it can demonstrate good cause for doing so.

\section{A. THE PUBlic USE/NAKED EYE QUAGMIRES}

I have already indicated the numerous possible meanings of "general public use." There are at least three broad definitions of that phrase (general availability, general use, and general use for a particular purpose) and each of those definitions can be subdivided into alternative definitions that vary widely. For instance, interpreting "general" to mean "of the whole," the general availability rubric might cover only the most common devices (such as flashlights or binoculars). In its "Wal-Mart" guise, however, it could also encompass zoom cameras, night vision equipment, and telescopes. Alternatively, if one takes Dow Chemical's use of the term seriously, then even

87. A caveat to this conclusion is that $K y l l o$ rejected the four factors discussed above only in connection with home searches that do not use generally available technology. Thus, when police looking into a home rely on technology in general public use, the Court might still call the action a Fourth Amendment search if what is viewed is "intimate," the technology replicates more than could be seen through unenhanced viewing, or one of the other factors is implicated. 
$\$ 22,000$ mapmaking cameras qualify. In contrast, the general use rubric, in its narrowest version, might not even include binoculars, because that item is probably not routinely used by most of the population. But "general use" could also fairly be construed to include that device, as well as any other device used by a large subgroup of the population (including airplanes and zoom cameras).

The general use for a particular purpose definition, although ostensibly the narrowest of the three, could still encompass many devices-or it could exclude all of them, depending upon whether a positivist or empirical approach is taken, and on which "purpose" is at issue. As a matter of positive law, use of binoculars and flashlights on the public thoroughfares is permissible; thus, if one were to follow the plurality's approach in Riley (which apparently considered curtilage viewing from any flight within navigable airspace near an air-lane to be "routine"), ${ }^{88}$ such use might not be a search even if it happened to disclose activities inside the home. As an empirical matter, however, people may seldom use public vantage points to peer into other people's homes, and fewer still use binoculars or flashlights, much less more sophisticated equipment, to do so; one could probably say such instances are "rare." Under the narrowest definition of general public use (for a particular purpose), even home observation aided by the most widely adopted forms of "technology"-eyeglasses, for instance-might thus constitute a search.

In short, the possible permutations of the general public use doctrine are myriad and perhaps overwhelming. To this problem, which admittedly besets other legal doctrines as well, is added the vexing quandary alluded to by the Kyllo dissent: How are the courts to deal with the rapid pace of technological development in deciding whether something is in general public use? Although the Court has declared that thermal imagers do not fit in this category, it may have to change its stance in the future, given the increasing reliance on such devices. ${ }^{89}$ Night vision equipment, although also relatively new, is even more ubiquitous and much less expensive, ${ }^{90}$ and will raise per-

88. See supra text accompanying notes 58-59.

89. Today, thermal imaging devices are relied upon fairly routinely by a large number of groups, including firefighters, doctors making diagnoses, and those engaged in maritime navigation, maintenance of electrical apparatus, product development and industrial production quality assurance. See www.flir.com (last visited April 12, 2002). 
plexing questions as well. If a declaration that these items are in general public use is hard to imagine, consider that the zoom camera-a device that at least two courts have considered generally available ${ }^{91}$ did not come into being until $1986 .^{92}$ Advanced technology can find its way in to the average home very quickly. ${ }^{93}$ When that happens with devices such as nightscopes and beepers (and perhaps thermal imagers?), the courts will either have to change their stance, manipulate the meaning of the general public use doctrine, or ignore it. None of these options is very palatable, either as an institutional matter (for courts used to following precedent), or as a policy matter (for police, litigants, and citizens trying to organize their affairs).

Conscientious courts will also be flummoxed by Kyllo's position on police use of technology that is not in general public use. Here they must determine whether the details seen with technology would also have been viewable with the naked eye without physically intruding into a constitutionally protected area. The first conundrum raised by this formulation is its inherently paradoxical nature. If naked eye viewing without physical intrusion could have occurred, why didn't it? If the answer is (and it usually will be) that the police were worried they would be discovered, thus leading the targets to stop what they were doing or to hide it better, then the interior details could not have been seen with the naked eye. In other words, Kyllo's naked eye formulation will often create an investigative catch-22: Either naked eye observation is possible without detection, ${ }^{94}$ in which case enhancement devices are not needed, or

90. Compare cost figures for thermal imagers, supra note 8 , with cost figures for night vision equipment, supra note 55 .

91. See supra note 42.

92. KEITH WILSON, PHOTOGRAPHY 10 (1994).

93. At one time, of course, even flashlights and binoculars were new on the market. But within a very short time, they became widely available to the public. See Invention of the Flashlight, at http://inventors.about.com/ library/inventors/blflashlight.htm (noting that the flashlight was invented in 1898 and was being heavily advertised the next year) (last visited Mar. 9, 2002); Peter Abrahams, The Early History of the Binocular, at http://home.europa.com/ telscope/binohist.txt (stating that the first high quality modern binoculars were sold in 1894) (last visited Mar. 9, 2002); Peter Abrahams, U.S. Army Binoculars: WWI, at http:/home.europa.com/ -telscope/milusarm.txt (explaining that by World War I over 100,000 binoculars were bought by the U.S. Army alone) (last visited Mar. 9, 2002).

94. Sometimes enhancement devices might be used not because they avoid detection but because they cost less than naked eye observation (e.g., naked eye observation that would have required an elaborate deception, such as officers posing as telephone line repair people). If so, the catch-22 is 
the details are not observable in that manner, in which case enhancement is not permissible. The Court probably did not intend that result. Assuming so, it has left courts with the puzzles of determining the extent to which fear of detection should be factored into the analysis, and how to discern whether that fear existed.

Putting this problem aside would not end the difficulties associated with the Court's ruling. Again, that ruling holds that enhanced searches of the home are permissible if they merely duplicate naked eye searches from vantage points that are not constitutionally protected. Many imponderables will surely arise in making this determination. Is the curtilage always a constitutionally protected area? What if it "invites" the public onto it with sidewalks and similar arrangements? Do apartment buildings have curtilage? Assuming the hypothetical naked eye viewing could take place without physical intrusion on a protected area, are there any other restrictions on how it could occur? Can it be hypothesized that police would have climbed trees, peered through cracks, and looked between halfdrawn curtains in determining whether the naked eye would have spied the activities actually observed with the enhancement device?

Lower courts have already had trouble grappling with these types of questions in dealing with actual naked eye viewing of the interior of the home. Although virtually all courts hold that looking through an open door or window from a public vantage point is not a search, in other situations one court's sufficiency of precaution is another court's complete failure to take adequate steps to protect privacy. Cases often come down to whether curtilage is secluded enough, a fence high enough, a

avoided, but the second problem with the naked eye exception, discussed further below, is not-how is a court to assess whether this more costly operation would have occurred and what it would have allowed the police to see? Enhancement devices might also be used to "confirm" naked eye observation. See, e.g., State v. Holbron, 648 P.2d 194, 197 (Haw. 1982) (finding no search where binoculars are used only to confirm unaided observations). In this type of case, however, the enhanced observation sees more detail than the naked eye; otherwise, "confirmation" wouldn't be necessary. See Robert C. Power, Technology and the Fourth Amendment: A Proposed Formulation for Visual Searches, 80 J. CRIM. L. \& CRIMINOLOGY 1, $49-50$ (1989) (objecting that in cases like Holbron "objects that officials can see but not fully identify without enhancement are treated as if they were in full public view").

95. See 1 LAFAVE, supra note $2, \S 2.3(\mathrm{c})$, at 480 (observing that "the prevailing rule" is that using the senses to investigate the interior of a residence from a lawful vantage point is not a search). 
curtain drawn enough, or a crack in the door small enough. ${ }^{96}$ Because it requires courts to speculate whether a hypothetical naked eye could have lawfully observed what the enhanced viewing detected in such circumstances, Kyllo's formulation profoundly exacerbates an already difficult judicial task. ${ }^{97}$

\section{B. TECHNOLOGICALlY ENHANCED OBSERVATION AND KNOWING EXPOSURE TO THE PUBLIC}

The problems with the general public use and naked eye doctrines go much deeper than difficulties in pinning down their meaning. Ultimately neither doctrine is sufficiently grounded in Fourth Amendment theory, either as laid out in Katz or as a more general proposition. This conclusion is particularly evident when one tries to connect these doctrines with Katz's "knowing exposure" language.

As Part I explained, ${ }^{98}$ in Ciraolo the Supreme Court relied on the statement in Katz that activities "knowingly expose[d] to the public, even in [the] home or office" do not deserve Fourth Amendment protection, and Kyllo later cited Ciraolo to bolster its adoption of the general public use exception. Yet the logical connection between this aspect of Katz and the Court's rules concerning technologically enhanced home surveillance is ex-

96. Compare, e.g., State v. Taylor, 401 N.E.2d 459, 462 (Ohio Ct. App. 1978) (looking into an apartment from the "semi-public walkway" leading to the building is not a search), with State v. Carter, 569 N.W.2d 169, 178 (Minn. 1997) (looking into an apartment window from the common area just outside the apartment window where bushes had to be walked around is a search), and Borum v. United States, 318 A.2d 590, 592 (D.C. 1974) (looking through a crack or hole in an apartment door is not a search). Compare State v. Morrow, 291 N.W.2d 298, 299 (Wis. Ct. App. 1980) (looking under a door is a search), with Moody v. State, 295 So. 2d 272, 273-74 (Ala. Crim. App. 1974) (looking through partially open blinds is not a search), and State v. Jordan, 631 P.2d 989, 990, 992 (Wash. Ct. App. 1981) (looking through a space between drape and window frame is a search). Compare Commonwealth v. Hernley, 263 A.2d 904, 905-06 (Pa. Super. Ct. 1970) (peering into a window using a four-foot ladder is not a search), with State v. Kender, 588 P.2d 447, 449, 451 (Haw. 1978) (climbing three-quarters of the way up a fence and bracing oneself on a fellow officer's shoulder to see into a backyard is a search). The last two cases involved uses of enhancement devices.

97. Even more daunting is the possibility that the general use and naked eye exceptions could work together, so that no search occurs when police use novel technology to spy what naked eye viewing or viewing with technology in general use could have observed. Because observation with generally used technology is apparently meant to be equated with naked eye observation in terms of privacy expectations, this bootstrapping of the two exceptions is not implausible.

98. See supra text accompanying notes 31-36. 
tremely tenuous. Almost by definition, activities in the home that are observed using enhancement devices are not " $k$ nnowingly" exposed to the public. As suggested above, police usually use technology because they want to ensure the target does not know about the surveillance and because they believe naked eye viewing is not feasible.

The only cases cited by the Katz opinion to support its "knowing exposure" language were Lewis v. United States" and United States v. Lee. ${ }^{100}$ Both involved scenarios quite different from enhanced observation of the home. In Lewis, the Court held that no search occurred when an undercover agent entered Lewis's home after Lewis had invited him there under the impression he wanted to buy drugs. ${ }^{101}$ In contrast to the person subjected to covert technological surveillance, Lewis knew he was disclosing information to a third party. ${ }^{102}$ In Lee, the Court held that no search occurred when government agents used a searchlight to discern cans of alcohol on the deck of Lee's boat. $^{103}$ Whether or not Lee knowingly exposed these cans to public view (arguably he intended to hide them under cover of darkness), they were clearly positioned on the equivalent of the boat's curtilage, not in its interior, a point the Court seemed to find important when it stated, "[i]t is not shown that there was any exploration below decks or under hatches."104 In Lewis, there was "knowing" exposure. In Lee, the home interior was not involved. The Kyllo scenario differs from both.

Virtually all of the Court's post-Katz decisions finding that the Fourth Amendment is not implicated fit one of these two molds. Either the defendant knowingly revealed information to a third party, who turned the information over to the government, ${ }^{105}$ or the exposure did not occur inside the home or its

99. 385 U.S. 206 (1966).

100. 274 U.S. 559 (1927).

101. 385 U.S. at 211 ("[W]hen, as here, the home is converted into a commercial center to which outsiders are invited for purposes of transacting unlawful business, that business is entitled to no greater sanctity than if it were carried on in a store, a garage, a car, or on the street.").

102. I would argue Lewis did not knowingly expose anything to the "public." I believe a search occurred in Lewis, but I also think it was justified under the Fourth Amendment. See infra note 165 and accompanying text.

103. 274 U.S. at 561, 563 ("Such use of a searchlight is comparable to the use of a marine glass or a field glass. It is not prohibited by the Constitution.").

104. Id.

105. See, e.g., Maryland v. Macon, 472 U.S. 463, 465 (1985) (information displayed in public store); Smith v. Maryland, 442 U.S. 735, 737 (1979) (to phone company); United States v. Miller, 425 U.S. 435, 442-43 (1976) (to 
curtilage. $^{106}$ Taken together, the Court's cases stand for the proposition that covert (i.e., undetected) observation of activities inside the home triggers the Fourth Amendment.

There is admittedly one post-Katz case involving government seizure of information from inside the home that does seem to have jettisoned the "knowing" requirement. In Smith v. Maryland, ${ }^{107}$ the Court held that even if a person does not know that the numbers he calls are recorded by the phone company, he "assume[s] the risk" that they will be. ${ }^{108}$ Similarly, it might be said, one assumes the risk that those activities inside the home that can be seen with generally used technology or by a (hypothetical) naked eye observer from outside the home will in fact be viewed in those ways.

Assumption of risk reasoning in this context is vacuous, however. The most pertinent illustration of that fact is that until the Supreme Court decision in Kyllo, in most jurisdictions we "assumed the risk" that police would subject the interior of our houses to thermal imaging without obtaining a warrant or developing any level of suspicion that evidence of crime would be discovered. ${ }^{109}$ As I have observed elsewhere, "we only assume those risks of unregulated government intrusion that the courts tell us we have to assume." ${ }^{\text {"110 }}$ Utimately, despite Katz's constant citation by the lower courts and the Supreme Court, the proper query is not the one posed by Justice Stewart's majority opinion in Katz or by a modified (assumption of risk) version thereof that focuses on what the target did or did not know or suspect. Rather, it is the inquiry suggested by Justice Harlan's

bank); Hoffa v. United States, 385 U.S. 293, 296 (1966) (to friend); United States v. On Lee, 343 U.S. 747, 749 (1952) (information voluntarily revealed to undercover agent).

106. Ciraolo, Dow Chemical, and Riley all involved flyovers of the curtilage. See supra text accompanying notes 32-39; see also California v. Greenwood, 486 U.S. 35, 37 (1988) (garbage at curbside); United States v. Dunn, 480 U.S. 294, 304 (1987) (open fields); Oliver v. United States, 466 U.S. 170, 173 (1984) (open fields).

107. 442 U.S. 735 (1979).

108. Id. at 744 (noting that although the petitioner may have had a subjective expectation that the phone numbers he dialed were private, "[w]hen he used his phone, petitioner voluntarily conveyed numerical information to the telephone company and 'exposed' that information to its equipment in the ordinary course of business. In so doing, petitioner assumed the risk that the company would reveal to police the numbers he dialed.").

109. Prior to Kyllo, a majority of jurisdictions had declared that use of thermal imagers was not a search. See supra note 2 and accompanying text.

110. Slobogin, supra note 66, at 400 . 
concurring opinion in that case: Is suspicionless observation of the home interior using enhancement devices something that "society is prepared to recognize as 'reasonable" ?"111 Kyllo itself accepted this point, and it is to that issue I now turn.

\section{TECHNOLOGICALLY ENHANCED OBSERVATION AND} REASONABLE EXPECTATIONS OF PRIVACY

As the Kyllo majority recognized, "[t] he Katz test-whether the individual has an expectation of privacy that society is prepared to recognize as reasonable-has often been criticized as circular, and hence subjective and unpredictable."112 Yet, the Court continued, at least "in the case of the search of the interior of homes-the prototypical and hence most commonly litigated area of protected privacy-there is a ready criterion, with roots deep in the common law, of the minimal expectation of privacy that exists, and that is acknowledged to be reasonable."113 From this premise the majority reached its holding that enhanced surveillance, relying on technology that is not in general public use and that detects more detail than any lawful naked eye observation could have, is a search. "This," claimed the Court, "assures preservation of that degree of privacy against government that existed when the Fourth Amendment was adopted." "14

Thus, the Court bottomed its analysis of privacy expectations vis-à-vis enhanced home surveillance on historical assumptions. To the extent the Court believed history supported the general public use and naked eye exceptions to its holding, it may well be wrong. In any event, if the scope of the Fourth Amendment as applied to technological surveillance depends on expectations "society is prepared to recognize as reasonable," we ought to consult more recent sources than attitudes that pre-existed the invention of flashlights and binoculars by over 100 years $^{115}$ (and most other technological surveillance techniques by almost two centuries). Modern law and empirical work suggests that society is not prepared to recognize either exception.

As far as history is concerned, there is not much to go on.

111. Katz v. United States, 389 U.S. 347, 360 (1967) (Harlan, J., concurring).

112. Kyllo v. United States, 533 U.S. 27, 34 (2001).

113. Id.

114. Id.

115. See supra note 93. 
The Kyllo majority quotes the famous statement from the seminal English case Entick v. Carrington ${ }^{116}$ that "the eye cannot by the laws of England be guilty of a trespass." 117 Although that statement is irrefutably true, given that the common law of trespass required a physical intrusion, it does not answer the historical question posed in Kyllo, which is whether naked eye or nominally enhanced viewing of the home violated colonial notions of privacy. ${ }^{118}$ Other than its quote from an English case, Kyllo provides nothing in support of its view that the typical eighteenth century American was unfazed when strangers spied into his or her home from a public vantage point. In contrast, we do know that the drafters of the Fourth Amendment were obsessed with protecting the security of the house. As John Adams put it,

An Englishmans [sic] dwelling House is his Castle. The Law has erected a Fortification round it-and as every Man is Party to the Law, i.e. the Law is a Covenant of every Member of society with every other Member, therefore every Member of Society has entered into a solemn Covenant with every other that he shall enjoy in his own dwelling House as compleat a security, safety and Peace and Tranquility as if it was surrounded with Walls of Brass, with Ramparts and Palisadoes and defended with a Garrison and Artillery. ${ }^{19}$

Professor Davies's comprehensive treatment of Fourth Amendment history confirms that, at the time the Constitution was drafted, the law provided that "except for extraordinary circumstances, an officer could not justify 'breaking' (that is, opening) the outer door of a house unless he acted pursuant to a judicial warrant."120 Further, as Professor Davies points out, "breaking" constituted virtually any interference with the

116. 19 How. St. Tr. 1029, 1066, 95 Eng. Rep. 807 (K.B. 1765) (Early English law reporters sometimes offer different accounts of the same proceedings. The English Reports version is provided for easy retrieval of the case; however, the quotation is from Howell's State Trials version.).

117. The Court actually quoted Boyd v. United States, 116 U.S. 616, 628 (1886), which in turn quoted at length from Entick.

118. The Court itself recognized this point even in the days when trespass doctrine governed the definition of search. In McDonald $v$. United States, 335 U.S. 451 (1948), in the course of holding that looking over a door transom was a search, the Court rejected the argument that "the eye cannot commit the trespass condemned by the Fourth Amendment," stating it would not "stop to examine that syllogism for flaws" but that it did "reject the result" that notion would have required in McDonald. Id. at 454.

119. 1 LEGAL PAPERS OF JOHN ADAMS 137 (L. Kinvin Wroth \& Hiller B. Zobel eds., 1965) (quoting Adams's notes of his argument in the 1774 case King $v$. Stewart).

120. Thomas Y. Davies, Recovering the Original Fourth Amendment, 98 MICH. L. REV. 547, 643 (1999) (footnote omitted). 
home, including something as slight as "lifting up the latch."121 If moving a latch was a search requiring a warrant in colonial times, peering into a window could easily have been considered one as well.

Providing substantiation of that conjecture is the fact that civil lawsuits involving "Peeping Toms" were heard in New England as early as the seventeenth century. ${ }^{122}$ Further, several American and English cases in the eighteenth century and the first half of the nineteenth century permitted criminal prosecutions for eavesdropping from a vantage point outside the home. ${ }^{123}$ Although technically these prosecutions focused on "listening toms" rather than "peeping toms," at least one of them involved a defendant who "was proved to have watched at the window of the chamber of the prosecutrix" and was upheld because "no man has a right ... to pry into your secrecy in your own house." ${ }^{124}$ In any event, by the end of the nineteenth century, civil and criminal trespass law in leading jurisdictions clearly prohibited window-peering. ${ }^{125}$ As one decision in 1897 opined, "[w]e cannot conceive of any conduct much more indecent and insulting than for a stranger to be peeking into the windows of an occupied, lighted residence, and especially at the

121. Id. at n.261 (quoting 4 WLLIAM BLACKSTONE, COMMENTARIES ON THE LAWS OF ENGLAND 226 (1769) (reprinted facsimile The University of Chicago Press, 1979)); see also Curtis v. Hubbard, 1 Hill 336, 338 (N.Y. 1841) (holding that "[1]ifting a latch is, in law, just as much a breaking, as the forcing of a door bolted with iron").

122. After describing prosecutions for eavesdropping, Professor Flaherty states,

Peeping Toms were similarly held up to ignominy at law [in colonial times]. A New Haven man won a slander and defamation suit against a fellow citizen who had accused him of coming "in the night to peep in at his window." John Severns of Salisbury entered a complaint against two young men in 1680, "for hovering about his house, peeping in at the window."

DAVID H. FLAHERTY, PRIVACY IN COLONIAL NEW ENGLAND 89 (1972).

123. See, e.g., State v. Williams, 2 Tenn. (2 Overt.) 108 (1808). Blackstone's description of the laws of England in the eighteenth century included within the "common nuisance" category "[e]avesdroppers, or such as listen under walls or windows or the eaves of a house, to harken after discourse, and thereupon to frame slanderous and mischievous tales." 4 BLACKSTONE'S COMMENTARIES ON THE LAWS OF ENGLAND 132 (Wayne Morrison ed., 2001).

124. Commonwealth v. Lovett, 6 Clark's Pa. L.J. Reps. 226, 226-27 (1831).

125. City of Grand Rapids v. Williams, 70 N.W. 547, 548 (Mich. 1897) (affirming a conviction for disorderly conduct for peering into a window near midnight); Moore v. N.Y. Elevated R.R., 29 N.E. 997, 997-98 (N.Y. 1892) (granting damages for an apartment dweller's loss of privacy due to exposure to an elevated train platform). 
hours of night when people usually retire."126

More importantly, this notion retains viability today. At least twenty-five states have statutes that criminalize looking into the home, under labels such as "voyeurism," "criminal surveillance," "criminal trespass," or simply "disorderly conduct."127 Convictions under such laws, including very recent ones, have often been based simply on evidence that the defendant was seen peering into a window, with intent to invade privacy inferred from the conduct. ${ }^{128}$ Tort caselaw similarly indicates that "spying into windows of a home" can lead to compensable injury for invasion of privacy or the tort of intrusion. ${ }^{129}$ These

126. Williams, 70 N.W. at 548 .

127. See, e.g., ALA. CODE § 13A-11-32 (1994); ARIZ. REv. STAT. ANN. § 131504 (West 2001); ARK. CODE ANN. § 5-71-213(a)(8) (Michie 1987); CAL. PENAL CODE $\$ 647(\mathrm{k})$ (West 1999); DEL. CODE ANN. tit. 11, § 820 (2001); FLA. STAT. ANN. § 810.14 (West 2000); GA. CODE ANN. § 16-11-61 (1999); HAW. REV. STAT. § 711-1111 (1993); IDAHO CODE §18-7006 (Michie Supp. 2001); 720 ILL. CONIP. STAT. ANN. 5/26-1(5) (West 1993); IND. CODE ANN. § 35-45-4-5 (Michie 1998); LA. REV. STAT. ANN. \& 14:284 (West 1986); MINN. STAT. § 609.746 (2000); MISS. CODE ANN. § 97-29-61 (2000); N.J. STAT. ANN. § 2C:18-3 (West 1995); N.C. GEN. STAT. § 14-202 (1999); OHIO REV. CODE ANN. § 2907.08 (Anderson 1999); OKLA. STAT. ANN. tit. 21, § 1171 (West 1983); R.I. GEN. LAwS \$ 11-45-1(6) (2000); S.C. CODE ANN. § 16-17-470 (Law. Co-op. 1975); S.D. CODIFIED LAWS § 22-21-3 (Michie 1998); TENN. CODE ANN. § 39-13-607 (Supp. 2001); VA. CODE ANN. $\$ 18.2-130$ (Michie 1996). For limitations imposed by some of these laws, see infra notes 129-32 and accompanying text. Massachusetts, Oregon, and the District of Columbia have affirmed convictions for voyeurism under disorderly conduct statutes. See Commonwealth v. Lepore, 666 N.E.2d 152, 156 (Mass. App. Ct. 1996) (construing the Massachusetts disorderly conduct statute to include voyeurism); Carey v. District of Columbia, 102 A.2d 314, 315 (App. D.C. 1954) (construing a disorderly conduct statute to permit conviction for voyeurism); DeLashmitt v. Journal Publ'g Co., 114 P.2d 1018, 1019 (Or. 1941) (describing imposition of a fine for "looking in the windows of another's home"). Since most states have disorderly conduct statutes, in theory peeping toms could be prosecuted in most other states as well.

128. See, e.g., J.F.C. v. City of Daphne, 2001 WL 564263, at *3-4 (Ala. Crim. App. May 25, 2001) (finding evidence sufficient to find a juvenile guilty of criminal surveillance, even though the state did not establish that the juvenile saw a person inside the apartment into which he was peeping, where the sheriff testified that he saw the juvenile late at night crouched below a window of the apartment, peering into the window, and when the sheriff identified himself as a law enforcement officer and instructed the juvenile and a companion to stand still); Mosely v. State, 166 S.E. 455, 455-56 (Ga. Ct. App. 1932) (affirming conviction of a defendant found squatting under a shrub near a lighted uncurtained bedroom window at 11:40 p.m.); Copeland v. Commonwealth, 525 S.E.2d 9, 11 (Va. Ct. App. 2000) (affirming conviction of window peeping).

129. See, e.g., Wolfson v. Lewis, 924 F. Supp. 1413, 1432 (E.D. Pa. 1996) (finding "a reasonable likelihood of success on the merits of [plaintiffs'] claim for invasion of privacy based on intrusion upon seclusion" when a media crew 
laws send the message that society is not prepared to recognize unjustified spying on the residence as reasonable.

Most of the criminal laws prohibiting voyeurism require trespass as an element of the offense. ${ }^{130}$ But some do not. For instance, in Louisiana a "Peeping Tom" is defined as "one who peeps through windows or doors, or other like places, situated on or about the premises of another for the purpose of spying upon or invading the privacy of persons spied upon without the consent of the persons spied upon." ${ }^{131}$ As this language asserts, "[i]t is not a necessary element of this offense that the 'Peeping Tom' be upon the premises of the person being spied upon."132 At least five other' states have similar statutes, ${ }^{133}$ and several

used a shotgun mike, binoculars, and zoom cameras to monitor activity inside a home); Gonzales v. Southwestern Bell Tel. Co., 555 S.W.2d 219, 221 (Tex. Civ. App. 1977) ("An intrusion upon a plaintiffs seclusion or solitude amounting to an invasion of privacy includes eavesdropping upon private conversations by wiretapping, microphones or spying into windows of a home."); PROSSER \& KEETON ON THE LAW OF TORTS 855 (W. Page Keeton ed., 5th ed. 1984) (citing cases holding that the tort of intrusion "is to be applied to peering into the windows of a home"). The Restatement states that "[o]ne who intentionally intrudes, physically or otherwise, upon the solitude or seclusion of another or his private affairs or concerns, is subject to liability to the other for invasion of his privacy, if the intrusion would be highly offensive to a reasonable person." RESTATEMENT (SECOND) OF TORTS § 652B (1977).

130. Several also limit conviction to those who have a "lewd" intent or some other sexual motivation. See, e.g., FLA. STAT. ch. 810.14(1) (2000) (requiring "lewd, lascivious, or indecent intent"); MISS. CODE ANN. § 97-29-61 (2000) ("lewd, licentious and indecent purpose"); OHIO REV. CODE ANN. § 2907.08 (Anderson 1999 \& Supp. 2001) ("for the purpose of sexually arousing or gratifying the person's self"); R.I. GEN. LAWS § 11-45-1(a)(6) (2000) ("lascivious purpose"); TENN. CODE ANN. § 39-13-607(a)(2) (2001) (similar language). Two also exclude from their purview officers involved in "lawful criminal investigation." VA. CODE ANN. § 18.2-130 (Michie Supp. 2001); see also MINN. STAT. § 609.746(f) (2000).

131. LA. REV. STAT. ANN. \$ 14:284 (West 1986) (emphasis added).

132. Id.; see also Souder .v. Pendleton Detectives, Inc., 88 So. $2 \mathrm{~d} 716,718$ (La. Ct. App. 1956).

133. ARK. CODE ANN. $§ 5-71-213(8)$ (Michie 1997) ("on or about the premises of another"); GA. CODE ANN. § 16-11-61(a) (1999) ("on or about the premises of another"); IND. CODE ANN. § 35-45-4-5 (Michie 1998) (penalizing "a person who peeps "into an occupied dwelling of another"); OKRA. STAT. ANN. tit. $21, \S 1171$ A (West Supp. 2002) ("Every person who hides, waits or otherwise loiters in the vicinity of any private dwelling house, apartment building or any other place of residence... with the unlawful and willful intent to watch, gaze, or look upon any person in a clandestine manner, [is guilty of a misdemeanor]."); S.C. CODE ANN. \& 16-17-470 (Law. Co-op. 1985) ("on or about the premises of another"); see also N.J. STAT. ANN. \& 2C:18-3 (West Supp. 20012002) (penalizing a person who, "knowing that he is not licensed or privileged to do so, ... peers into a window or other opening of a dwelling"); N.C. GEN. STAT. \$14-202 (1999) ("Any person who shall peep secretly into any room oc- 
other jurisdictions construe their laws to cover non-trespassory surveillance, ${ }^{134}$ or define trespass very loosely. ${ }^{135}$ Thus, in these states, naked eye viewing that does not involve physical intrusion into constitutionally protected areas can be a crime.

Even in those states that require clear proof of trespass for a Peeping Tom violation, the kind of viewing Kyllo places outside the ambit of the Fourth Amendment might be a crime, depending on how the courts define "constitutionally protected area." Many courts have refused to include certain types of curtilage in that definition ${ }^{136}$ (a stance with which at least one member of the Supreme Court agrees ${ }^{137}$ ). In those jurisdictions, voyeurism from such curtilage areas would not implicate the Fourth Amendment as construed in Kyllo. But it would still be a crime in trespass states, because curtilage is private prop-

cupied by a female person shall be guilty of a Class 1 misdemeanor.").

134. See, e.g., Carey v. District of Columbia, 102 A.2d 314, 315 (D.C. 1954) (affirming the voyeurism conviction of a defendant who stood on "the lawn outside the window" but emphasizing the act of looking, stating, "[w] hat action could be more disturbing, offensive, or insulting than to have a total stranger peeping into the window of one's lighted apartment, especially at 1:30 in the morning?"); People v. Miller, 415 N.E.2d 538 (Ill. App. Ct. 1980) (finding valid the arrest for disorderly conduct of an individual found in a walkway next to a women's dormitory at nine p.m.); Commonwealth v. LePore, 666 N.E.2d 152, 155-56 (Mass. App. Ct. 1996) (affirming a conviction for disorderly conduct when defendant looked in a window from an alleyway); Gov't v. Stagger, 13 V.I. 233 (1977) (conviction for "disturbing the peace" upheld where the defendant stood on the ledge of an adjacent building and looked into a lighted room).

135. See, e.g., J.F.C. v. City of Daphne, $2001 \mathrm{WL} 564263$, at *2 (Ala. Crim. App. May 25, 2001) (stating that "even if an individual is generally licensed and privileged to use the common areas of the property on which the apartment building is situated, the would violate the criminal surveillance provision by] using the common areas in a manner so as to invade the privacy of the residents of other apartments located on the property"); State v. Serrano, 702 P.2d 1343 (Ariz. Ct. App. 1985) (affirming a conviction for criminal trespass of the individual who looked into a lighted dorm window from bushes lining the side of the dorm).

136. See, e.g., Lorenzana v. Superior Court, 511 P.2d 33, 35 (Cal. 1973) (en banc) ("A sidewalk, pathway, common entrance or similar passageway offers an implied permission to the public to enter which necessarily negates any reasonable expectancy of privacy in regard to obser[v]ations made there.").

137. See Minnesota v. Carter, 525 U.S. 83, 103-04 (1998) (Breyer, J., concurring) (arguing that there was no Fourth Amendment violation when "the apartment in question was a garden apartment that was partly below ground level; ... . families frequently used the grassy area just outside the apartment's window for walking or for playing;... members of the public also used the area just outside the apartment's window to store bicycles; ... . [and the officer] walked to a position about 1 to $11 / 2$ feet in front of the window [and] stood there for about 15 minutes looking down through a set of venetian blinds"). 
erty. Further, most of the Peeping Tom statutes that require trespass do not contemplate the possibility of home viewing using enhancement devices that obviate such an intrusion; the one statute that does (California's) eliminates the trespass element in this situation. ${ }^{138}$ This suggests that, when states begin to focus on surveillance using enhancement equipment, the trespass requirement will go by the wayside.

Finally, there is some empirical evidence suggesting that society considers home surveillance using enhancement devices to be more intrusive than the Supreme Court seems to think. In a study that I conducted with Joseph Schumacher, 217 subjects were asked to rate the relative intrusiveness of 50 scenarios taken from Supreme Court and lower court cases. ${ }^{139}$ The responses of the subjects, averaged together, provided a hierarchy of intrusiveness, ranging from looking through foliage in a public park $(R=1)$ to a body cavity search $(R=50){ }^{140}$

Most interesting for present purposes were the rankings assigned to the three scenarios involving enhancement devices-shining a flashlight down a dark alley next to a home $(R=3)$, flying 400 yards above a backyard in a helicopter $(R=10)$, and watching a person in a front yard using binoculars $(\mathrm{R}=33) .{ }^{141}$ The flyover was ranked roughly the same as two scenarios involving roadblocks $(R=9 ; R=14)$, an action the courts have held implicates the Fourth Amendment (although stops made at such checkpoints need not be based on individualized suspicion). ${ }^{142}$ More importantly for the subject of this Article,

138. Compare CAL. PENal CODE $\S 647($ i) (West 1999 \& Supp. 2002) (prohibiting "peek[ing] in the door or window of any inhabited building or structure" while "loitering, prowling, or wandering upon the private property of another"), with id. $\$ 647(\mathrm{k})$ (Supp. 2002) (prohibiting "look[ing] through a hole or opening into, or otherwise view[ing], by means of any instrumentality, including, but not limited to, a periscope, telescope, binoculars, camera, motion picture camera, or camcorder, the interior of a bathroom, changing room ... or the interior of any other area in which the occupant has a reasonable expectation of privacy, with the intent to invade the privacy of a person or persons inside"). See also Derek L. Kinnen, 8 Hilliard Men Charged in Case, FLA. TIMes-UnIon, Sept. 15, 2001, at P-2 (stating that a man was charged with voyeurism after found walking on the beach near midnight looking in people's windows with binoculars).

139. Christopher Slobogin \& Joseph Schumacher, Reasonable Expectations of Privacy and Autonomy in Fourth Amendment Cases: An Empirical Look at "Understandings Recognized and Permitted by Society," 42 DUKE L.J. 727, 735-37 (1993).

140. Id. at 737-39 tbl.1.

141. Id.

142. See, e.g., Mich. Dep't of State Police v. Sitz, 496 U.S. 444, 450 (1990) 
the scenario involving binocular surveillance of the front yard was ranked at roughly the same level of intrusiveness as examination of a car trunk $(R=29)$, a footlocker in a car $(R=32)$, and a garage $(R=37),{ }^{143}$ all actions the courts consider to be searches requiring probable cause. ${ }^{144}$ Although not scenarios included in the study, use of binoculars to look into a house would presumably have been ranked as even more intrusive, and unenhanced spying on the home interior would probably have also been ranked as fairly intrusive, at least at the same level as binocular viewing of a front yard.

Thus, evidence from history, positive law, and social science casts significant doubt on Kyllo's apparent conclusion that societal mores concerning privacy are not transgressed by suspicionless surveillance of the home interior carried out with devices that are in general public use or that can see what the naked eye could see from a lawful vantage point. This conclusion, especially when combined with the inscrutability of the general use and naked eye doctrines discussed earlier, argues for a different holding in Kyllo: Peering into the home by government officials, at least when it relies on enhancement devices, should always be considered a Fourth Amendment search. The next section explores how this notion can be implemented.

\section{TWO POST-KYLLO PROPOSALS}

A rule that all technological spying on the interior of the home is a search not only captures society's expectations of privacy-whether defined historically or by today's standardsbut can also easily be reconciled with the language of the Fourth Amendment. To "search" means "to look into or over carefully or thoroughly in an effort to find or discover something."145 The Fourth Amendment prohibits unreasonable searches of houses. Thus, as many others have pointed out ${ }^{146}$

(stating that "[p]etitioners concede, correctly in our view, that a Fourth Amendment "seizure' occurs when a vehicle is stopped at a checkpoint," and requiring that the selection and operation of the checkpoint be "reasonable" under the Fourth Amendment).

143. See Slobogin \& Schumacher, supra note 139, at 738.

144. See, e.g., United States v. Ross, 456 U.S. 798 (1982) (requiring probable cause for a search of a car); Taylor v. United States, 286 U.S. 1 (1932) (requiring probable cause for the search of a garage).

145. WEBSTER'S NEW COLLEGIATE DICTIONARY 1042 (1973).

146. The classic statement is from Professor Amsterdam. "The plain meaning of the English language would surely not be affronted if every police activ- 
(and even Kyllo intimated ${ }^{147}$ ), it does not stretch the Fourth Amendment in the slightest to say it is implicated when police look carefully or thoroughly for something inside a house.

If that were the rule, then under current Fourth Amendment jurisprudence all governmental peering into houseseven naked eye viewing - would require probable cause, as well as a warrant in non-exigent circumstances. The obvious protest against this interpretation is that it would seriously hamper police investigation. Police with suspicion short of probable cause to believe that criminal activity is taking place inside a home would be unable to verify their suspicion through observation, either with or without a warrant. Indeed, a cynic might claim that it is this concern, not history or assessments of society's privacy expectations, that best explains Kyllo's general public use and naked eye exceptions.

I have previously proposed a regulatory approach that would allow police the benefit of their observations, inadvertent and otherwise, without sacrificing individual privacy interests. ${ }^{148}$ Although "search" would be broadly construed under this proposal, so too would "probable cause" (to mean "that cause which makes probable the reasonableness of the intrusion occasioned by a given search or seizure"). ${ }^{149}$ Thus, the level of cause needed to justify a search would depend upon its intrusiveness. Probable cause, as currently defined, would not always be necessary to peer into the home interior. As noted

ity that involves seeking out crime or evidence of crime were held to be a search. ... Unless history restricts the amplitude of language, no police investigative activity can escape the Fourth Amendment's grasp." Anthony Amsterdam, Perspectives on the Fourth Amendment, 58 MINN. L. REV. 349, 396 (1974).

147. 533 U.S. 27, 32 \& n.1 (2001) ("One might think that ... examining the portion of a house that is in plain public view ... is a 'search.' ... When the Fourth Amendment was adopted, as now, to 'search' meant '[t]o look over or through for the purpose of finding something; to explore; to examine by inspection; as, to search the house for a book; to search the wood for a thief.") (citation omitted).

148. My first effort on this score was in 1991, and was updated in 1998 in a symposium on Terry $v$. Ohio. See Christopher Slobogin, The World Without a Fourth Amendment, 39 UCLA L. REV. 1 (1991) [hereinafter Slobogin, Fourth Amendment]; Christopher Slobogin, Let's Not Bury Terry: A Call for Rejuvenation of the Proportionality Principle, 72 ST. JOHN'S L. REV. 1053 (1998) [hereinafter Slobogin, Proportionality Principle].

149. Slobogin, Fourth Amendment, supra note 148, at 76. This definition would still permit a robust warrant requirement, because warrants could still be based on "probable cause," as required by the Fourth Amendment. Id. at 77-78. 
years ago by Professor Amsterdam, the practical advantage of this proportionality approach is that it "would considerably ease the strains that the ... monolithic model of the Fourth Amendment ... imposes on the process of defining the amendment's outer boundaries."

Although the proportionality principle can be reconciled with the Fourth Amendment, ${ }^{151}$ it does cut against the grain of standard Fourth Amendment search jurisprudence. ${ }^{162}$ A second proposal that has more solid legal precedent and that could also address the problems raised by Kyllo is patterned on Title III's prohibition of warrantless electronic communications surveillance. Analogous legislation banning particular forms of enhanced visual surveillance could in effect nullify both the general public use and naked eye exceptions.

\section{A. THE PROPORTIONALITY PRINCIPLE}

Here is the first sentence of a recent news story: "When Sgt. John Shupe went looking for a serial thief last month, he packed his car with the tools of his trade: a night-vision telescope, high-resolution binoculars, a camcorder and a shotgun." ${ }^{153}$ The story goes on to note that Shupe's team has carried out over 400 surveillance operations in the past year, which led to 127 arrests. ${ }^{154}$ It does not describe how the various enhancement devices Shupe carries are employed. If Shupe were to use any of these items to peer randomly into homes from his car, on the off chance he would spy the serial thief, would he be violating the Fourth Amendment? Very possibly not, after Kyllo. The camcorder and binoculars could easily be considered items that are in general public use, and the scope might be as well. Even if they are not, any activities that Shupe sees while using them that might also have been seen by the casual observer on the sidewalk could well be covered by

150. Amsterdam, supra note 146 , at 393.

151. See Slobogin, Fourth Amendment, supra note 148, at 75-78.

152. See, e.g., Arizona v. Hicks, 480 U.S. 321, 328-29 (1987) (responding to the suggestion that a cursory inspection might require reasonable suspicion rather than probable cause, the majority stated, "[w]e are unwilling to send police and judges into a new thicket of Fourth Amendment law, to seek a creature of uncertain description that is neither a 'plain view' inspection nor yet a 'full-blown search.' Nothing in the prior opinions of this Court supports such a distinction ....").

153. Laura Loh, Specialists in Surveillance Get Their Man, L.A. TIMES, Dec. 26, 2001, at B3.

154. Id. 
the naked eye exception. A final resolution of these matters would depend upon which definition of general public use is adopted and how easily naked eye viewing from a lawful vantage could be hypothesized.

Now consider another story, this one a description of the pre-Kyllo case of United States $v$. Wright. ${ }^{155}$ At 4:20 p.m., police located the remains of a stolen car under circumstances indicating that it had been stripped in that vicinity. ${ }^{156}$ During a systematic sweep of the surrounding area, they found sweepings of nuts and bolts, as well as red rags similar to those found next to the car's carcass, in front of a three-car garage facing onto an alley. ${ }^{157}$ The sliding doors of the garage, although locked, were not completely closed because of the way they were constructed and their age. ${ }^{158}$ Although it was daytime, Officer Huffstutler used his flashlight to look through the door gap into the garage interior and see parts that had been removed from the stolen car. ${ }^{159}$ The majority held that use of the flashlight was not a search, ${ }^{160}$ while the dissent emphasized that the garage doors were locked and stated, "[c]ertainly a flashlight is not standard equipment for 'any curious passerby,' particularly in the daytime." If flashlights are in general public use, which is the case under most definitions of that term, then the majority's holding seems to be more consistent with Kyllo. On the other hand, if one takes the empirical, general use for a particular purpose approach adopted by the dissent, then perhaps the officer's actions did constitute a search. On the third hand, the inside of the garage was only "relatively dark" according to the court (meaning the flashlight was useful but not absolutely necessary), ${ }^{162}$ and the officer was kneeling on public property when he peered inside, so perhaps the naked eye exception would apply here.

Under the proportionality approach, both Shupe's surveillance of home interiors and Huffstutler's exploration of the ga-

155. 449 F.2d 1355 (D.C. Cir. 1971).

156. Id. at 1356.

157. Id.

158. Id.

159. Id.

160. See id. at 1359 ("It has long been settled that objects falling in the plain view of an officer who has a right to be in the position to have that view are subject to seizure and may be introduced in evidence.").

161. Id. at 1368 (Wright, J., dissenting).

162. Id. at 1356. 
rage would be searches. Whether these searches were valid under the Fourth Amendment would depend upon the level of justification and the level of intrusion. If Shupe randomly peered into houses, then he would be violating the Fourth Amendment, because his suspicion is too minimal for even a slight intrusion into the home. ${ }^{163}$ If, however, he is in a neighborhood thought to be a target of the serial thief, he should be able to use his binoculars and nightscope to scan rooftops, yards, and house exteriors for suspicious movement and, if he spies any, focus on that movement long enough to ascertain its nature, even if it involves viewing inside a window and even in the absence of full probable cause. Similarly, Huffstutler's observation of the car parts and rags gave him sufficient cause, even if not probable cause, for a brief look at the interior of a garage with or without a flashlight. ${ }^{164}$

Under proportionality analysis, the ubiquity of the enhancement device the police use is entirely irrelevant. So is any inquiry into whether the details observed through enhancement could have been viewed with the naked eye from a lawful vantage point. The only issues are the level of intrusion visited by the police action and the level of justification for it.

The two significant practical advantages of this approach should be apparent. First, it avoids the complications associated with the general public use and naked eye doctrines. Second, as suggested by Professor Amsterdam, it avoids the strains placed on courts and the police by the rigid searchrequires-probable-cause precept. In most of the Court's cases that address the definition of "search" for Fourth Amendment purposes, the police have had sufficient suspicion under a proportionality approach to justify their enhanced searches. ${ }^{165}$

163. In contrast, simply viewing homes from the patrol car as an officer drives down the street would not be a search, since it does not involve looking "carefully or thoroughly in an effort to find or discover something." See supra text accompanying notes $145-46$.

164. In non-exigent circumstances such as those involved in Wright, however, I would require the police to obtain a warrant before engaging in a search of a particular dwelling. See Slobogin, Fourth Amendment, supra note 148 , at 37 ("Exigent circumstances would exist only when government investigators are confronted with imminent violence to others, disappearance of evidence, or escape of a suspect. Otherwise, the search and seizure should be approved beforehand.").

165. See Slobogin, Proportionality Principle, supra note 148, at 1073. This is true not only of the cases directly relevant to this Article, but also of other cases that define "search." Take, for instance, the Supreme Court's decisions in Lewis and Lee. See supra text accompanying notes 99-104. In Lewis, the 
Thus, had the Supreme Court adopted that approach, it "could have had its cake and eaten it too."166

The proportionality idea also makes sense conceptually. Under the monolithic approach, courts are encouraged, as the majority was in Wright, to declare actions that are clearly searches to be non-searches. That result leaves a huge range of intrusive police actions completely unregulated by the Fourth Amendment, including, most probably, use of flashlights and binoculars to look in our homes. At the same time, under current rules no search, even a relatively unintrusive one, can take place unless police have full-blown probable cause. As I have argued elsewhere, ${ }^{167}$ that result runs counter to legal reasoning in a number of other constitutional and non-constitutional domains, where the required justification need only be proportionate to the impact of the government intervention.

The usual criticism of the proportionality idea, also advanced by Professor Amsterdam, is that "a graduated Fourth Amendment"168 would become "one immense Rorschach blot."169 I have previously responded to this criticism in detail. ${ }^{170}$ The

defendant had offered to sell the police drugs over the phone and invited them to his house to consummate the sale, giving them probable cause sufficient to enter Lewis's home. Lewis v. United States, 385 U.S. 206, 207 (1966). In Lee, the Coast Guard followed the defendant's boat to a point 24 miles offshore commonly referred to as "Rum Row" where it docked with a French boat, giving it minimal suspicion, but sufficient to shine a searchlight on the exterior of Lee's boat. United States v. Lee, 274 U.S. 559, 560 (1927). Both Lewis and Lee involved searches, but under a proportionate definition of cause, both were also justified.

166. Slobogin, Proportionality Principle, supra note 148, at 1073.

167. Id. at 1068-69 (discussing standards of proof in criminal and civil proceedings, levels of scrutiny in constitutional litigation, procedural due process analysis, and proof requirements in the tort context).

168. Amsterdam, supra note 146, at 393.

169. Id. Elsewhere Professor Amsterdam has even choicer words for the proportionality approach. Id. at 415 (calling the approach "splendid in its flexibility, awful in its unintelligibility, unadministrability, unenforcibility and general ooziness").

170. See Slobogin, Proportionality Principle, supra note 148, at 1093-95 (noting that current law is already complicated, that a proportionality approach based on four tiers of cause is administrable, that concrete rules would eventually develop, and that the ex ante review requirement would prevent arbitrary actions); Slobogin, Fourth Amendment, supra note 148, at 71-75 (proportionality approach would allow courts and police to do openly what they do in any event). It is worth noting that Professor Amsterdam, although leery of a graduated Fourth Amendment, stated that "the difficulty must be faced and the line must be drawn because the total exemption of police espionage from Fourth Amendment control seems to me destructive of at least some interests of privacy and security that are indispensable to a free society." Am- 
only point I will make here is that, contrary to Professor Amsterdam's suggestion, the courts are quite capable of dealing with the proportionality approach. Most obviously, they have been applying a graduated Fourth Amendment in the seizure context since at least Terry $v$. Ohio. ${ }^{171}$ Further, despite what they say, courts often taken the same approach where searches are involved. Exhibit One is once again Terry, which held that a frisk only requires reasonable suspicion. ${ }^{172}$ Consider also one of the leading enhancement device cases, United States $v$. Karo. ${ }^{173}$ There the Supreme Court held that use of a beeper to detect movement inside a house is a search, but also indicated that a warrant for such a search might be valid even if based on reasonable suspicion rather than probable cause. ${ }^{174}$ Although not provided by the Court, the rationale for allowing a lower level of suspicion might be that a beeper does not reveal the detail that direct visual observation does; whereas, as Kyllo held, the precise capacity of the device used is not relevant to whether a search occurs when the target is a house interior. It might help define the level of justification necessary for such a search under proportionality analysis. ${ }^{175}$

The lower courts routinely engage in proportionality analysis as well. For instance, in Wright, the case described above, the majority gave as an alternative ground for its holding the fact that, though the police may not have had probable cause,

sterdam, supra note 146 , at $408-09$. He also suggests that flexible rules can be devised through police administrative rulemaking rather than judicial fiat. Id. at 417-18 (arguing that administrative rulemaking need not be "limited to the warrants and the probable cause standard").

171. 392 U.S. 1, 23 (1968) (holding that stops short of arrest are permissible based on reasonable suspicion). A number of other Supreme Court cases permit seizures based on something short of probable cause. See, e.g., Michigan v. Summers, 452 U.S. 692 (1981) (holding that an occupant of a house may be detained for the duration of the search of the house pursuant to a warrant); Pennsylvania v. Mimms, 434 U.S. 106 (1977) (per curiam) (requiring the driver of a stopped car to exit does not require suspicion)United States v. Martinez-Fuerte, 428 U.S. 543 (1976) (holding that a checkpoint stop for illegal immigrants does not require probable cause or reasonable suspicion).

172. 392 U.S. at 23.

173. 468 U.S. 705 (1984).

174. See id. at 718 ("It will be time enough to resolve the probable causereasonable suspicion issue in a case that requires it.").

175. See also United States v. Place, 462 U.S. 696, 723 (Blackmun, J., concurring in the judgment) ("[A] dog sniff may be a search, but a minimally intrusive one that could be justified in this situation under Terry upon mere reasonable suspicion."). 
they had developed sufficient cause to look into the garage. ${ }^{176}$ Similar holdings are found or implied in a number of other decisions. ${ }^{177}$ The role of the courts under an explicit proportionality approach would simply be to determine "how much explanation for a given intrusion is necessary to convince an innocent person subjected to it that the police acted reasonably,"178 no more and no less.

Kyllo does not necessarily reject this approach in the context of enhanced surveillance of the home. Both the general public use and naked eye doctrines could be characterized as dicta. ${ }^{179}$ Or, both doctrines might be defined so narrowly that

176. United States v. Wright, 449 F.2d 1355, 1357-60 (D.C. Cir. 1971) (discussing a "closer look at a challenging situation" and "plain view" as alternative justifications, with the former assuming a search occurred, albeit perhaps in the absence of probable cause).

177. See United States v. Morehead, 959 F.2d 1489, 1496 (10th Cir. 1992) (looking into the window of a shop building near a residence is a search, but lawful because police had an arrest warrant for defendant and had reason to believe he was there); United States v. Concepcion, 942 F.2d 1170, 1173 (11th Cir. 1991) (turning the key in a lock is a search, but the intrusion was "so small" that neither a search warrant nor full probable cause was necessary); Dorsey v. United States, 372 F.2d 928, 930-31 (D.C. Cir. 1967) (holding, without addressing whether action was a search or was justified as such, that officers' shining light into a car upon seeing two known addicts facing each other and looking under seat was permitted, because police are entitled to "take a closer look at challenging situations as they encounter them"); United States v. Bassford, 601 F. Supp. 1324, 1331 (D. Me. 1985) ("[T]he brief surveillance involved in the present case ... was undertaken in response to the receipt of specific information concerning the cultivation of marijuana on the Bassford property."); State v. Torres, 645 A.2d 529, 534-35 (Conn. 1994) (assuming a dog sniff of a car was a search, but lawful because it was on "reasonable and articulable suspicion"); State v. Christensen, 953 P.2d 583, 588 (Idaho 1998) (holding that entry onto property marked with a "No Trespassing" sign was a search, but could be permissible without a warrant if something more serious than inquiries about nearby residents is the justification); State v. Cloutier, 544 A.2d 1277, 1280 (Me. 1988) (concluding that entry onto private property was permissible based on recent burglary reports in the area and the fact that the basement was the only illuminated room in the house, stating that to enter property "a police officer must be on some police business," which need not require probable cause or reasonable suspicion; it may be "administrative as well as investigative, and it may be action based on a suspicion that turns out to be without substantial basis, provided the suspicion is held in good faith rather than as a pretext for an arbitrary search").

178. Slobogin, Proportionality Principle, supra note 148, at 1084.

179. It is worth noting that the Kyllo majority never firmly adopted the general public use doctrine. In a footnote, it stated that general public use "may" be a factor in the search analysis, and intimated it might "reexamine" this factor in the future. 533 U.S. 27, 39 n.6 (2001) ("Given that we can quite confidently say that thermal imaging is not 'routine,' we decline in this case to reexamine that factor."). The naked eye doctrine was also unnecessary to its 
they have no practical impact. ${ }^{180}$ At the same time, following the suggestion in Karo, searches of houses (enhanced or not) that cannot by their nature reveal intimate details or that for some other reason are not particularly intrusive could be justified on something less than probable cause as traditionally defined.

\section{B. A LEgISLATIVE APPROACH}

Federal legislation has regulated electronic communications surveillance since 1968, when Congress passed the Omnibus Crime Control and Safe Streets Act, which most courts designate simply "Title III."181 Similar federal legislation regulating enhanced visual surveillance-a sort of national "Peeping Techno-Tom law"-might prove to be a worthy alternative to Kyllo, in addition to or instead of the proportionality approach. Here I briefly describe how Title III might serve as a model for that purpose.

Title III deals with interception of oral, wire, and electronic communications, but for present purposes the provisions regarding oral communication are most pertinent. Title III defines the latter type of communication as "any oral communication uttered by a person exhibiting an expectation that such communication is not subject to interception under circumstances justifying such expectation,"182 and defines "intercept" to mean "the aural or other acquisition of the contents of any ... oral communication through the use of any electronic, mechanical, or other device." ${ }^{\text {"183 }}$ It then prohibits all "intentional" interceptions of oral communications, so defined, unless they are judicially authorized or one of the parties to the com-

decision, as the thermal imager obviously detected more than the naked eye could see from a public vantage point.

180. For instance, if "general public use" were defined to require use by the entire population to carry out the activity in question, it would have no application in connection with home surveillance. If the naked eye doctrine were defined to require clear proof that all of the activities and items seen with the enhancement device could also have been seen with the naked eye from a completely public vantage point (e.g., sidewalks, but not curtilage or other areas abutting the home), then it too would have little purchase.

181. See 18 U.S.C. $\$ \S 2510-2520$ (2000). This federal statute preempts state law on electronic surveillance. See id. $\$ 2516(2)$; $c f$. United States v. Tortorello, 480 F.2d 764 (2d Cir. 1973).

182. 18 U.S.C. $\S 2510(2)$.

183. Id. $\$ 2510(4)$. 
munication consents to the interception. ${ }^{184}$ Violations can lead not only to exclusion of evidence, but to civil and criminal penalties. ${ }^{185}$

One important effect of these provisions is that they criminalize all nonconsensual electronic eavesdropping by civilians. Other parts of Title III reinforce this prohibition by banning the manufacture and sale of "any electronic, mechanical, or other device [that is] primarily useful for the purpose of the surreptitious interception of . . . oral . . . communications. ${ }^{\text {"186 }} \mathrm{Al}$ though ordinary interception devices (such as tape recorders) are not covered by this provision, hidden recorders or microphones may be. ${ }^{187}$

With important modifications, these provisions can be applied in the visual surveillance context. First, just as unauthorized interceptions of oral communications are prohibited, the proposed statute would ban nonconsensual, warrantless "visual surveillance" of "private locations." 188 The latter term could be defined as "the interior of the home and all other areas in which activities are carried out or items possessed by people exhibiting an expectation that such activities or items are not subject to surveillance under circumstances justifying such an expectation." "Visual surveillance" could be defined as "the viewing of a private location using any electronic, mechanical, or other device." If that definition is viewed as too broad (it would include viewing private locations with eyeglasses as well as cameras, for instance), the phrase "that enhances normal (20-20) vision" could be added. Any intentional visual surveillance of private locations, so defined, would be prohibited

184. Id. $\S 2511(2)$. There are a few other exceptions to the prohibition that are not pertinent here. See generally id. $\$ 2511$.

185. Id. $\S 2511(4)$, (5) (respectively criminal penalties and civil suits).

186. Id. § 2512(1).

187. See United States v. Biro, 143 F.3d 1421, 1427 (11th Cir. 1998) (holding that $\$ 2512$ encompasses "pens, wall plugs, and calculators containing concealed transmitters"); United States v. Pritchard, 745 F.2d 1112, 1123 (7th Cir. 1984) (finding that a "briefcase containing a tape recorder, an amplifier, a voice activation unit, a power source, and [various] patch cords" was "sufficient basis" for a $\$ 2512$ conviction); United States v. Wynn, 633 F. Supp. 595 (C.D. III. 1986) (holding that a "Drop-In Telephone Microphone" was clearly covered by $\$ 2512$ ).

188. Note that several courts have, in effect, already extended Title III in this fashion to the regulation of video surveillance of homes and like places. See, e.g., United States v. Falls, 34 F.3d 674, 679-80 (8th Cir. 1994); United States v. Koyomejian, 970 F.2d 536, 538-39 (9th Cir. 1992); United States v. Torres, 751 F.2d 875, 884-85 (7th Cir. 1984). 
unless judicially authorized or at least one of the parties under surveillance consents to it.

Another aspect of the proposed statute would, like Title III, seek to limit the proliferation of surveillance devices. Unauthorized manufacture, sale, or possession of visual surveillance equipment that is "primarily useful for the purpose of the surreptitious visual surveillance of private locations" could be prohibited. Devices that could see images through walls and video cameras that are designed to be secreted in briefcases and clothing clearly fall in this category. Binoculars, flashlights, nightscopes, and telescopes clearly do not. Devices such as thermal imagers and beepers fall at the margin. Perhaps with respect to these types of devices, legislation could place limitations on their purchase and possession similar to those that exist with surreptitious listening devices. ${ }^{189}$

Because it bans warrantless, nonconsensual technological surveillance of "private locations," defined to include the interior of residences, this statute should render virtually irrelevant both the general public use and naked eye exceptions to the extent they allow suspicionless, covert technological surveillance of the home. Analogous exceptions under Title III have been rejected. For instance, one court found that, although the defendant's voice could often be heard through his open office door, monitoring of those conversations using eavesdropping equipment violated the statute. ${ }^{190}$ Parallel reasoning in the visual surveillance context would make the naked eye exception untenable. Similarly noteworthy are Congress's vacillations on whether Title III protects the radio portion of cordless telephones. In 1986, Congress amended Title III to exclude conversations on such phones from the ambit of the statute on the theory that they could be intercepted using "readily available technologies" such as an AM radio. ${ }^{191}$ In 1994, however, it reversed itself, ${ }^{192}$ presumably for reasons similar to

189. See 18 U.S.C. $\$ 2512(2)$ (permitting possession of surreptitious listening devices only by providers of communication services or "an officer, agent, or employee of, or a person under contract with, such a provider, in the normal course of the business of providing that wire or electronic communication service," and by government agents and those under contract with the government).

190. Walker v. Darby, 911 F.2d 1573, 1579 (11th Cir. 1990).

191. S. REP. No. 99-541, at 12 (1986), reprinted in 1986 U.S.C.C.A.N. 3555, 3566; accord Dorsey v. State, 402 So. $2 d 1178$ (Fla. 1981); State v. Howard, 679 P.2d 197 (Kan. 1984) (accord).

192. Pub. L. No. 103-414, § 202, 108 Stat. 4279 (1994) (codified at 18 U.S.C. 
those advanced here against the general public use exception in visual surveillance cases. In other words, under Title III privacy does not disappear simply because the technology used to conduct surveillance is generally available or picks up conversations in private areas that could be heard with the naked ear.

The statute would not, of course, "reverse" that part of Kyllo that adopts the general public use and naked eye exceptions, because they are interpretations of the Constitution. As a consequence, if the statute did not provide for an exclusionary remedy (as is the case for those provisions in Title III dealing with electronic, as opposed to oral or wire, communications ${ }^{193}$ ), then evidence obtained when these exceptions apply, although observed in violation of the statute, could still be used in court. But even in this situation the statute would have an impact. Because it would prohibit covert use of any technologyincluding commonly available devices such as flashlights and binoculars-to spy into homes, courts would be hard put to find that such items are in general public use for that purpose, whether they consider the issue empirically or as a matter of positive law. That position, in turn, should nullify Kyllo's general public use exception (unless the Court insists on defining the exception in terms of general use for any purpose). Moreover, because the statute would prohibit civilian possession of technology made primarily for covert spying of private locations, that type of technology would never become "generally used."

Less directly, the statute would also undermine Kyllo's naked eye exception. Although Congress could perhaps pass a national Peeping Tom statute, ${ }^{194}$ the proposed legislation does not purport to regulate naked eye observation of home interiors. Thus, unenhanced viewing of the home from a lawful vantage

\section{$\S 2510(a)(2000))$.}

193. See S. REP. No. 99-541, at 23 (1986), reprinted in 1986 U.S.C.C.A.N. 3555, 3577 (explaining that, after "discussions with the Department of Justice," it was decided not to require exclusion when the rules governing interception of electronic communications were violated).

194. One possible obstacle to such a statute is the Supreme Court's recent willingness to strike down statutes that are not clearly based on congressional powers authorized by the Constitution. See, e.g., United States v. Lopez, 514 U.S. 549 (1995) (holding that the Gun-Free School Zones Act, which makes it a federal offense for any individual to knowingly possess a firearm in a place that the individual believes or has reasonable cause to believe is a school zone, exceeded Congress's commerce clause authority). While a statute regulating technology that is sold across state lines meets this test, a statute that regulates naked eye viewing may not. 
point would not be illegal, at least under this statute, and government could still constitutionally avail itself of the naked eye exception when its technological surveillance discerns only what such viewing would discern. However, because the statute would prohibit unauthorized enhanced viewing of the home, whether undertaken by citizens or the police, the exception would lose considerable moral force.

\section{CONCLUSION}

The drafters of the Fourth Amendment believed the house should be sacrosanct. Kyllo leaves that fundamental principle in doubt. Its "general use" and "naked eye" exceptions to the general prohibition against enhanced visual observation of the home interior represent potentially huge loopholes in the Fourth Amendment's protection. Unless very narrowly defined, they are difficult to apply. More importantly, they would allow police to violate our reasonable expectations of privacy, whether defined by what we knowingly expose to the public, by history, by positive law, or by empirical investigation of societal mores.

The better approach is to designate all house surveillance a search, but modulate the cause necessary to carry it out. At the same time, the legislature should ensure that unauthorized use of technology to view the home never becomes routine by outlawing it. Otherwise, our most private sanctuary will become progressively less private. 
